Portland State University

PDXScholar

10-24-1995

\title{
Institutionalized Discrimination: Three Cases in the United States Military
}

Sarah H. Frost

Portland State University

Follow this and additional works at: https://pdxscholar.library.pdx.edu/open_access_etds

Part of the Sociology Commons

Let us know how access to this document benefits you.

Recommended Citation

Frost, Sarah H., "Institutionalized Discrimination: Three Cases in the United States Military" (1995). Dissertations and Theses. Paper 5021.

https://doi.org/10.15760/etd.6897

This Thesis is brought to you for free and open access. It has been accepted for inclusion in Dissertations and Theses by an authorized administrator of PDXScholar. Please contact us if we can make this document more accessible: pdxscholar@pdx.edu. 
THESIS APPROVAL

The abstract and thesis of Sarah H. Frost for the Master of Science in Sociology were presented october 24, 1995, and accepted by the thesis committee and the department.

COMMITTEE APPROVALS:
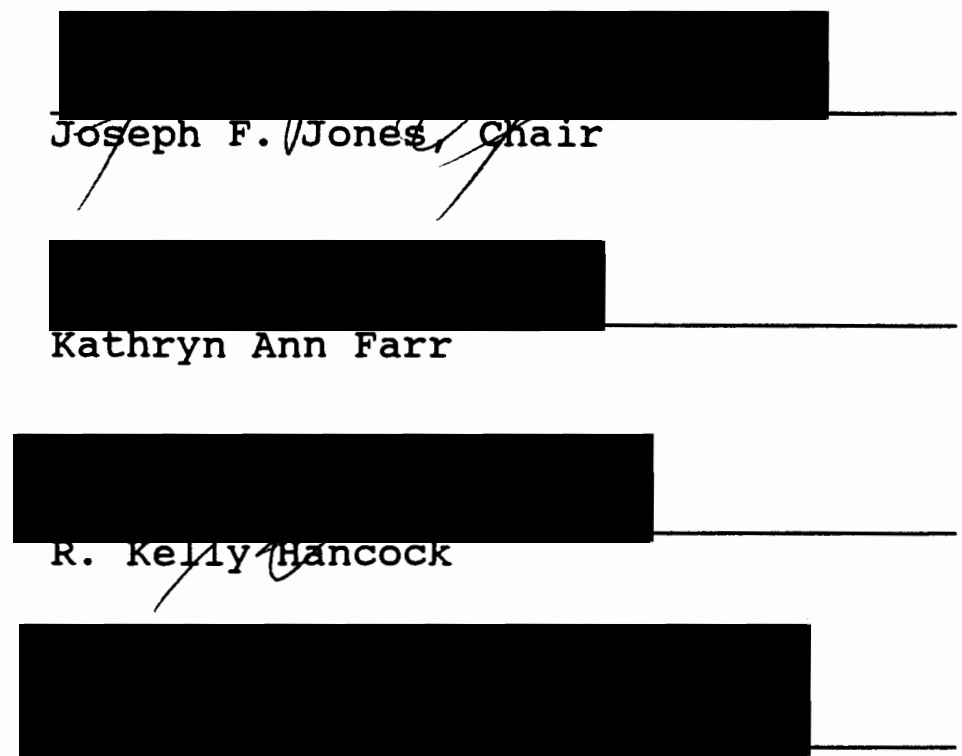

Dalton Milier-Jones

Representative of the

office of Graduate studies

DEPARTMENT APPROVAL:

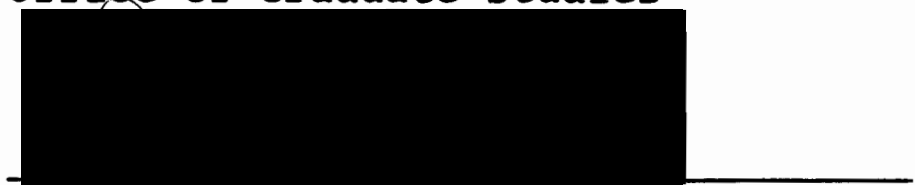

Robert W. Shotola, Chair

Department of Sociology

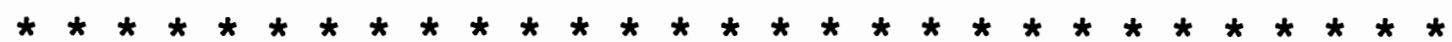

ACCEPTED FOR PORTLAND STATE UNIVERSITY BY THE LIBRARY

by

on 272 menter 1975 
ABSTRACT

An abstract of the thesis of Sarah $H$. Frost for the Master of Science in Sociology presented October 24, 1995.

Title: Institutionalized Discrimination: Three cases in the United states Military.

This thesis explores institutionalized discrimination in the United states Military by examining the rationales given for policies that exclude, or limit the military service of racial minorities, women and homosexuals, and the rationales given for altering such policies.

outgroups such as racial minorities, women and homosexuals are presumed to be a threat to the white male heterosexual majority within the military services. The presence of these outgroups in the military has been officially characterized as threatening to small-unit cohesion, and therefore threatening to military readiness.

This thesis was first based upon the assumption that the rationales favoring discriminatory policies, and rationales favoring reform, would be expressed in the language of small-group theories of cohesion, that is, cohesion based upon the self-categorization of group members, or the interdependence of group members. However, in the data analysis process, two other 
rationales emerged: the ideological and the bureaucratic rationales.

Data illustrating these four rationales were drawn from a content analysis of articles and other commentary published in the New York Times. Statements were crosstabulated by the stance (exclusionist or reformist) they supported and the rationale (self-categorical, interdependent, ideological or bureaucratic) they employed to justify the stance. This analysis was first done separately for each of the three groups, racial minorities, women and homosexuals, and then the data for each of the three outgroups were compared and contrasted. Findings indicate that despite the military's official characterization of outgroups as a threat to small-unit cohesion, relatively little of the debate was expressed in terms of small-group theories of cohesion-the self-categorization of, or interdependence of group members. The most frequently employed rationales were, in fact, ideological in character. Between the three groups, however, some differences in patterns of rationales and stances emerged.

The findings are placed in their historical and political contexts to help explain the results of the analysis, and to illuminate the experience of racial minorities, women and homosexuals in the United States military. 
INSTITUTIONALIZED DISCRIMINATION :

THREE CASES IN THE UNITED STATES MILITARY

by

SARAH H. FROST

A thesis submitted in partial fulfillment of the requirements for the degree of

\author{
MASTER OF SCIENCE \\ in \\ SOCIOLOGY
}

Portland State University

1995 


\section{ACKNOWLEDGEMENTS}

I want to take this opportunity to thank my friends, near and far, who lent their moral support during my tenure as a graduate student. Without their encouragement I might never have considered graduate school.

I wish to thank my thesis committee members for the time they took to work with me, and for their suggestions and comments. It is a better thesis for their efforts.

Finally I wish to express my sincere gratitude to Dr. Joseph F. Jones. Without his guidance, reassurances, wisdom, friendship, and occasional threats, this thesis might never have been completed. 
TABLE OF CONTENTS

PAGE

ACKNOWLEDGEMENTS ....................... ii

LIST OF TABLES ....................... vi

CHAPTER

I INTRODUCTION ....................... 1

Overview

Questions, Definitions and Assumptions

Overview of Methodology

II BACKGROUND AND THEORETICAI PERSPECTIVES........ 13

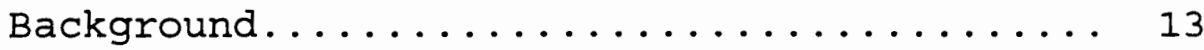

Introduction

Bureaucracy....................... 14

Characteristics of Bureaucracies

Limits of the Bureaucratic Model

The U.S. Military as a Bureaucratic

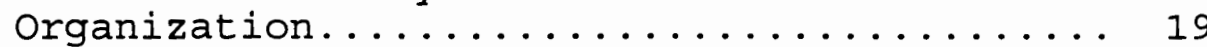

The Total Institution

Uniform Code of Military Justice

Summary of Background............... 28

Theoretical Perspectives.............. 29

Introduction

Self-Categorization

Interdependence

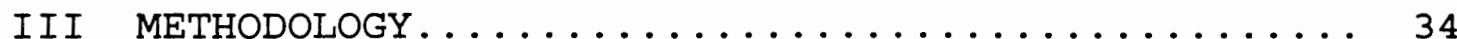

Introduction 


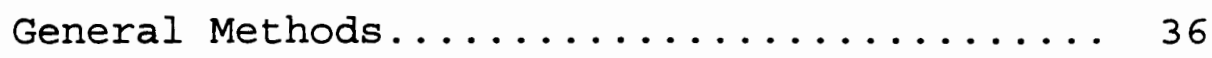

Racial Minorities

Women

Homosexuals

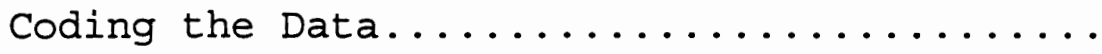

Overview

Codes

Inter-Rater Reliability

IV FINDINGS AND ANALYSIS................ 49

Racial Minorities................. 49

Introduction

Historical Perspective

Findings

Analysis

The Political Context

The Military Context

Women............................ 6

Introduction

Historical Perspective

Findings

Analysis

The Political Context

The Military Context

A Feminist Perspective

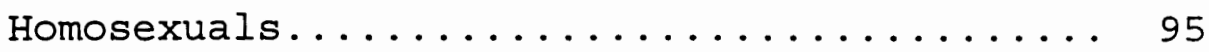

Introduction

Historical Perspective

Findings

Analysis

The Political Context

The Military Context

A Feminist Perspective

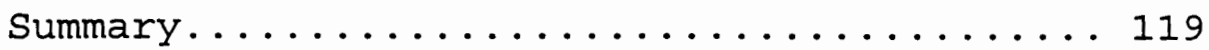

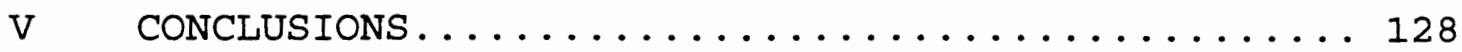




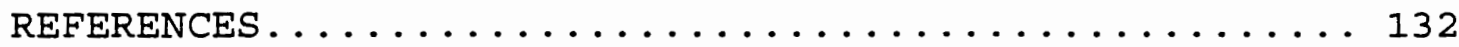

APPENDICES

A BIBLIOGRAPHY OF NEW YORK TIMES ARTICLES.... 138

B SUMMARY OF STATEMENT CLASSIFICATIONS

BY ARTICLE IDENTIFICATION NUMBER......... 147 


\section{LIST OF TABLES}

TABLE

PAGE

I Distribution of 97 statements Favoring

and Opposing Racial Desegregation in

the U.S. Military July 26, 1947 to

July $26,1949 \ldots \ldots \ldots \ldots \ldots \ldots \ldots \ldots \ldots \ldots \ldots \ldots \ldots \ldots \ldots \ldots \ldots$

II Distribution of 203 statements in Favor of, and opposition to subjecting women to Combat Duty and/or the Draft April 6, 1978

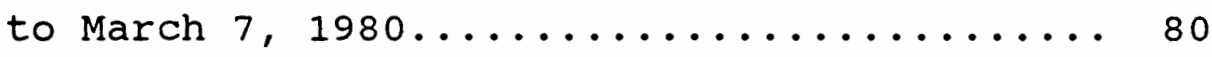

III Distribution of 353 statements in Favor of, and Opposition to Allowing Homosexuals to Serve in the U.S. Military May 28, 1993,

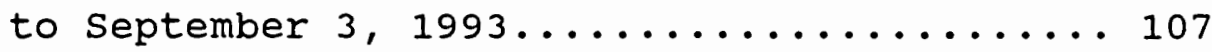

IV Summary Table of the Distribution of 653 statements Favoring and/or opposing Discriminatory Policies in the

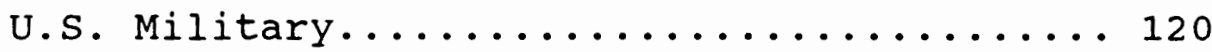

V Summary Table of the Distribution of 653 statements Favoring and opposing Discriminatory Policies in the United states Military stance by outgroup

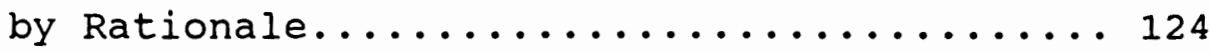


CHAPTER I

INTRODUCTION

\section{Overview}

The United States military is one of the country's oldest and largest bureaucratically organized social systems. While the bureaucratic model stresses the impersonal nature of that form of organization, personal characteristics and attitudes of members in fact affect organizational functioning (see, among others, Blau 1964; Homans 1958). Yet bureaucracies are predicated upon, and thrive on predictability. Characteristics and attitudes of members, because they cannot be controlled, become a potential liability for such organizations.

As a bureaucratic organization the United states military must find ways to mitigate the unpredictable nature of social interaction among its members. The attempt to control the behavior of service members has led to (among other things) a pattern of discrimination against categories of people. Presumably, a more homogeneous service membership is viewed as more predictable. The U.S. military has always been composed mostly of white, male and presumably heterosexual 
personnel. Because their presence might be deemed "offensive" to the majority, outgroups such as racial minorities, women and homosexuals are regarded as a threat to military discipline and morale, and therefore a threat to military readiness. Discrimination, in this context, is not so much an attempt to "keep down" its victims, as it is the result of taking the easiest route to reducing hostility between service members, thus reducing the threat to military readiness. The result, however, is the same-- unequal opportunity within the military, based upon categorical differences.

Racial minorities, women, and homosexuals have historically encountered various types of discrimination within the U.S. military. The limits placed on their participation include (or have included) restrictions from particular military vocations and/or ranks, exclusions from certain military stations or installations, or complete exclusion from military service (Nalty 1986; Holm 1982; Shilts 1993).

Given the supposed impersonal nature of bureaucracies, the fact that the military has fiercely resisted the inclusion of people because of group characteristics appears anomalous. Discrimination by the military is a particularly dubious practice because the military's separate body of criminal law -- the Uniform 
Code of Military Justice -- gives the organization unparalleled power to control the behavior of its members. Yet despite this power, the military has not chosen to enforce standards of behavior equally among service members. Instead, the possibility of hostile and inappropriate behaviors by one category of people toward another in the services has been "resolved" through institutionalized discrimination.

Individual prejudices, of course, cannot be eliminated through bureaucratic wrangling or legislation. But the issue addressed here is not whether service members dislike or act out against one another because of their categorical differences. It is acknowledged that prejudice, and resultant discriminatory behaviors, exist among service members. The more important fact is that the military itself institutionalizes discrimination from the top of the organization on down. Discrimination is codified, both in federal law and in service regulations. In other words, to not discriminate against certain categories of people has been, and still is, a breach of the organizational rules (Department of Defense directive [hereafter DOD dir] 1332.14; Wells-Petry 1993, p. 5).

A fundamental paradox is evident here. The U.S. military exists for the purpose of defending not only America's citizens and soil, but also American ideology. 
Themes of freedom and justice are found throughout the U.S. Constitution and the Bill of Rights. The right to equal protection under the law for all citizens of the United States is guaranteed in the 14 th Amendment of the constitution. It states that "privileges or immunities" of U.S. citizens must be ensured.

Yet the military -- the organization whose purpose is to protect and defend these doctrines -- violates the spirit (and frequently the letter) of the constitution by systematically discriminating against categories of people.

There are indications that the military does not need to institutionalize discrimination to curb inappropriate or hostile behaviors by some service members toward others. The power of the military organization to influence the behaviors of its members is reflected in this paradox: some members of the military are not prejudiced toward other people, yet are forced by law or regulation to discriminate; while other members who are prejudiced toward others are forced by the same legal apparatus (regulations banning sexual harassment, etc.) to refrain from discriminating. This paradox illustrates Merton's (1976, p. 192) typology of ethnic prejudice and discrimination:

(S) O far as the beliefs of individuals are concerned, we can identify two types: those who 
genuinely believe in the creed [of prejudice] and those who do not.... similarly, with respect to actual practices: conduct may or may not conform to the creed. And further, this being the salient consideration: conduct may or may not conform with individuals' own beliefs concerning the moral claims of all people to equal opportunity.

Stated in formal sociological terms, this asserts that attitudes and overt behavior vary independently. Prejudicial attitudes need not coincide with discriminatory behavior (emphasis in original).

The fact that prejudice and discrimination can operate independently suggests two points: first, discriminatory behavior might be suppressed no matter how service members feel toward one another; and second, discrimination can become institutionalized if the prejudices held by a small number of people -- those in charge of making the laws and setting the policies -- are codified into rules that all service members must follow. Therefore, the following examination of institutionalized discrimination in the military at times includes the necessarily related issues of individual prejudice and discrimination.

Questions, Definitions and Assumptions

The historical pattern of discrimination within the military inspires the question: If bureaucracies are meritocratic in character, why has the bureaucracy that is the U.S. military resisted the inclusion of perceived outgroups, whose characteristics have nothing to do with 
the manifest function of the military? A related question may be posed: What is the base for challenges to these practices?

Perhaps the perceived threat is not to bureaucratic functioning at all, but rather to the small working groups (units) in which service members interact on a much more personal level. The practical function of these small groups, which operate within the larger bureaucratic framework, may (or may not) depend upon a level of camaraderie among their members. People deemed undesirable to the majority of group members because of their categorical differences would pose an obvious threat to affective bonding within the group. The group would then be forced to rely upon the functional interdependence of its members-- the division of labor which requires all service members to perform their jobs proficiently in order for others in the group to do the same. Group cohesion based upon the functional interdependence of members could eliminate the necessity for affection among members, and instead require from them only a professional attitude toward one another and toward the military. Whether the military believes small unit cohesion is based upon camaraderie among service members, or upon their functional interdependence, could be the crucial factor in determining whether to risk policy changes that 
are more inclusive toward outgroups.

"The military" as used here is very broadly defined.

It generally refers to those services currently under the aegis of the United States Department of Defense: the Army, the Navy, the Air Force, and the Marine Corps. Also included are the reserve components of these services, the National Guard and the Air Guard, and the United states coast Guard. Further included are service academies, the Pentagon, and any service organization under the war Department until World War II but since then consolidated, renamed or disbanded.

The terms "category," "group" and "outgroup" are used throughout in reference to racial minorities, women and homosexuals. While there can be little dispute that "category" is an appropriate term for race, sex, and sexual orientation-- concepts which can be applied to people anywhere, the terms "group" and "outgroup" imply something different: smaller numbers of people, usually in the presence of one another, and who identify with one another, if the strict sociological definition is applied. Nonetheless, categorical distinctions such as race, sex and sexual orientation can and do cause divisions between people at the small-group level. Therefore all three terms -- category, group, and outgroup -- are considered appropriate terms for racial minorities, women, and 
homosexuals within the context of the following discussion.

Examined in this work are rationalizations supporting and opposing the inclusion of the above-named outgroups in the United states military. The following assumptions are made:

1. The U.S. military fits the bureaucratic model of organization as well as -- and often better than -other organizations stereotypically thought of as "bureaucracies."

2. Institutionalized discrimination against categories of people exists in the military, contradicting the bureaucratic model of organization.

3. The exclusion of outgroups from participation in the U.S. military will be justified or condemned with language that can be classified into the terms of small-group interaction-- the self-categorization of, or interdependence of service members.

4. "Reformists," who argue for a more inclusive military organization, will rely on the bureaucratic model of individual merit, or the small-group concept of interdependence to support their stance, because race, sex, and sexual orientation are not relevant to small-unit cohesion based upon interdependence; while "exclusionists," who argue for maintaining the 
discriminatory status quo, will rely upon the selfcategorical hostility toward outgroups to support their stance, because such outgroups are felt to threaten small-unit cohesion based upon camaraderie. "Exclusionists" argue that the role of the military as the defender of the United States is too important to subject it to social experiments in equality (Wells-Petry 1993, p. 170). "Reformists," who have pushed to make the military more inclusive argue that, besides being unfair, discrimination within the ranks does more damage to military readiness by putting unnecessary psychological strain on some service members than would occur by allowing equal opportunity for all people to serve (Davis $1991, p .103)$

By examining the constructions of meanings of participation in the military for three categories of people -- racial minorities, women, and homosexuals -limitations of the bureaucratic model will be explored in the following chapters. Ancillary concerns include such matters as the larger social contexts within which military service by these categories of people becomes less threatening to the military; historical changes in the meaning of their participation; and modes of accommodation that are utilized by both the military as an organization and by the affected members. 
Individual service members, of course, may be members of more than one of these "outgroup" categories. Such overlapping membership may be seen as placing people into unique categories which face discrimination that is not merely the sum of its parts; that is, a black woman may be placed in a category that is not merely a reflection of racism and sexism, but rather a more specific set of stereotypes that are applicable only to black women.

However, the possibility of overlapping outgroup membership is ignored here. This is because the military has not recognized such dual membership in the form of laws or regulations, and because the experiences of individual service members are viewed as less important than the treatment of the category as a whole. Therefore, the rationalizations for and against discrimination involving each outgroup are compared and contrasted as though group membership is exclusive.

\section{Overview of Methodology}

To examine the arguments for and against exclusionary policies in the military data were gathered from a daily newspaper -- the New York Times -- from periods surrounding each of three years: 1948, 1979, and 1993 (see the further discussion in Chapter III -- "Methodology"). It was during these years that legislative or regulatory changes profoundly affecting the military status of racial 
minorities, women, and homosexuals were debated or enacted.

There is an acknowledged weakness in using a newspaper as a source of data. News writing generally does not provide "scientific" examinations of issues. Nevertheless, it is considered important to use this source of data, because newspapers convey, and frequently help produce, cultural attitudes regarding issues. The media both shapes and reflects public perception. The New York Times was chosen because it is circulated nation-wide and therefore has the potential to reach people in all regions of the United States (see the further discussion in Chapter III -- "Methodology").

From discussions in the newspaper there emerge justifications for military policy as it stands as well as justifications for implementing changes in policy. These are first categorized by the policy position they support, that is, they are categorized as "exclusionist" if they support the exclusionary status quo, or "reformist" if they support more inclusive policy changes. The arguments are then further categorized by their rationale, that is, whether they invoke "interdependent" or "self-categorical" models of small-group cohesion as rationales for retaining or reforming military policy.

Given that the presence of outgroup members in the 
military is viewed as a threat to small-unit cohesion, it is reasonable to assume that the threat, once articulated, could easily be categorized into either self-categorical or interdependent models of cohesion. However, analysis of the data in chapter IV reveals that this is rarely so. Despite the perceived threat to small-unit cohesion, both exclusionist and reformist arguments most frequently invoke rationales which have nothing whatsoever to do with small group cohesion. 
CHAPTER II

BACKGROUND AND THEORETICAL PERSPECTIVES

\section{BACKGROUND}

\section{Introduction}

The contemporary United states military displays many characteristics of bureaucracies. The strict hierarchical structures which have always existed in the military are complemented by a division of labor that is becoming increasingly more complex. Technological developments in weaponry, communications, transportation, and other things necessary to wage war have forced the military organization to rely on the professionalization of its members (Janowitz 1959, p. 15).

Military service members are not unlike their civilian counterparts in other bureaucratic organizations. Therefore, an examination of the general characteristics of bureaucracies, and the ways in which they deal with their members, may illuminate some of the ways in which the military controls service members.

Both the strengths and weaknesses of the bureaucratic form of organization may be observed in the military. One of the strengths of bureaucracy is reflected in the 
military's organizational independence from individual service members. A critical weakness of bureaucracy is illustrated by human-relations and other problems within the military.

\section{BUREAUCRACY}

\section{Characteristics of Bureaucracies}

Max Weber's model of bureaucracy depicts an organizational form depending upon hierarchy, clear definitions of positions and rules for interaction, explicit goals, and the interdependence of organizational divisions to ensure cohesion (Weber 1946, pp. 196-98). The geographic areas covered by bureaucracies may be so vast, and the numbers of members so large, that it is an impossibility for members to become familiar with one another. Weber asserts that this is not a disadvantage for the person holding a position, or "office" in the bureaucratic organization, because the member's loyalty is to the office itself, rather than to other organizational members. As Weber states:

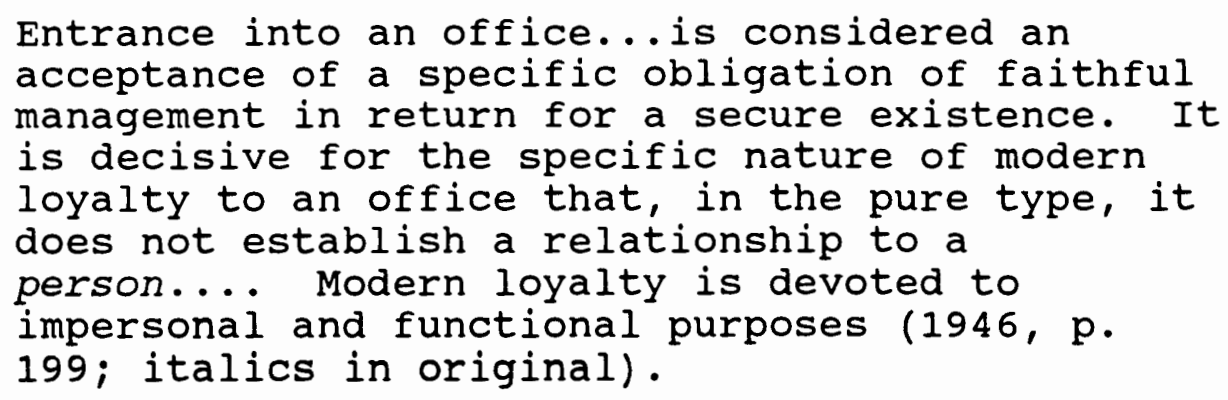


occupational responsibilities, then, are of paramount importance, while the personal characteristics of those who hold the jobs are of less importance.

This "rational" form of organization rests upon the idea that a formalized structure of social arrangements makes the personal characteristics of members irrelevant to the manifest function of the organization (Scott 1992, p. 31). Strict regulation of behavior lends stability and predictability to relationships among members. Understanding how they fit into the structure of the organization allows members to anticipate the actions of all other members, based upon an understanding of roles within the organization. Hypothetically, the only relevant differences between members are the types of organizational training and experiences they have had and the levels of authority they can exercise.

Formalization, then, allows an organization to replace one member with another of equal training, with minimal impact upon the function of the organization. The formalized social roles are independent of the members who fill them (Scott 1992, p. 33). Formal organizations are able to encourage cohesion among members through the interdependence of organizational units (Benveniste 1977, p. 6), and by enabling members to predict one another's behavior (Weber 1946, p. 214). 
The prescribed requirements for positions within the rational organization are designed, inter alia, to prevent members from occupying positions for which they are not qualified. Once members are qualified, they may fill those particular positions in any part of the organization. Positions are standardized, and therefore determine the roles that members employ when interacting with one another. In effect, members become parts of an organizational "machine." Weber (1946, p. 228) describes their situation:

[W] here the bureaucratization of administration has been completely carried through, a form of power relation is established that is practically unshatterable.

The individual bureaucrat cannot squirm out of the apparatus in which he is harnessed.... [T] he professional bureaucrat is chained to his activity by his entire material and ideal existence. In the great majority of cases, he is only a single cog in an ever-moving mechanism which prescribes to him an essentially fixed route of march (gender in the original).

Weber's description of formal organization implies that the characteristics or personalities of members make no difference to the functioning of formal organizations, as long as those members are able and willing to enact their roles. People are viewed as mechanized beings, with no concerns outside of the organization.

Yet humans are not machines, and cannot be expected to exist without the influence of emotions. Further, no organization can exist without members. Therefore, the 
characteristics, personalities, and concerns of members must affect organizations.

Limits of the Bureaucratic Model

Much effort has been given to the study of the reciprocal influences of bureaucratic organizations and their members (See, for example, Benveniste 1977; Blau 1974; Crozier 1964). Even the most standardized "predictable" organization must take into account the wild card of human behavior. Crozier's (1964) notion of the "human factor" suggests that organizational members' behaviors are influenced by their feelings-- sometimes despite the rules of the organization. If members are, in fact, motivated within the organization by feelings that are independent of organizational goals, their behaviors become more difficult to predict. In his conceptualization of "bureaucratic dysfunction," Crozier (1964, p. 179) describes this "human relations" approach to bureaucracy:

When one believes that human activities depend on the feelings and sentiments of the people involved, and on the interpersonal and group relationships that influence them, one cannot expect that imposing economic rationality on them will bring constant and predictable results. The functioning of a bureaucracy can never...be totally explained by the combination of impersonality, expertness, and hierarchy of the "ideal type."

The preceding commentary reinforces the view that 
interpersonal and group relationships cannot be separated from organizational function.

It is the nature of bureaucracies to react against the unpredictable human factor by imposing more rules and/or tougher sanctions against misbehavior (Palola and Jones 1965, p. 3). If organizations are to function at peak efficiency, they must acknowledge the possibility that members will work in the best interest of the organization only if they can be coerced into so doing. Cozier (1964, p. 179) continues:

The behavioral rigidity...that exist[s] in a bureaucracy reinforce[s] the need for control and regulation. Thus, finally, the unintended and dysfunctional results of the bureaucratic model tend to reinforce their hold. In human relations terms, dysfunction appears to be the consequence of the resistance of the human factor to standardized behavior that is imposed upon it mechanically.

Weber (1946) conceptualizes human emotion as an unpredictable liability which must be tightly controlled within organizations, or whenever possible, eliminated from them. Given that people are beings affected by emotion, and that people exist in all organizations, it is then important to examine how and why (or why not) people willingly work together within organizations. It is important because only by acknowledging that members' attitudes and characteristics affect bureaucracies can organizations begin to realize their greatest human resource potential. 
THE U.S. MILITARY AS A BUREAUCRATIC ORGANIZATION

The United States Military, as an organization, exemplifies the bureaucratic model. organizational definitions of jobs and responsibilities are so rigid and concise that the members who fill the roles are akin to interchangeable parts. Ostensibly, members' personal characteristics are irrelevant, so long as they perform their jobs and follow regulations.

Nonetheless, the military does discriminate against certain categories of people, even if individuals within those categories would otherwise meet the criteria of the job. For example, felons, the young and the aged, and conscientious objectors have been excluded from military service. Further, within the services, members routinely face discrimination on the basis of their height and weight, physical strength, visual and auditory acuity, and intelligence (Wells-Petry 1993, p. 5).

These criteria directly reflect the function of the military. Excluding or limiting service by people in these categories helps ensure that qualifications for jobs will be met. For example, to earn the label "felon," a person must have demonstrated an unwillingness or inability to function as a law-abiding member of society. Felons' supposed tendencies toward antisocial or erratic 
behavior make their service in the contemporary military too unpredictable, and therefore, useless. Middle-aged people are more likely than younger recruits to have developed medical problems that would compromise their ability to fill military jobs, thus limiting their service. Such people also generally have a bigger "stake" in life, because they have had more time to marry, settle into careers and acquire property, factors to which Becker (1960, p. 35) refers as "side bets." Further, society itself has a "stake" in middle-aged people, who are employed in needed professions, contributing the most money into the tax base, and exercising their purchasing power. People younger than 17 years are considered too immature, both psychologically and physically, to handle the responsibility of military service: Conscientious objectors, by definition, have made statements that they will refuse to obey certain orders -- to carry a weapon, for example -- thus making their service incompatible with many of the military's needs.

Within the services (as within other organizations), people with limited sight or hearing, or a lack of intelligence or strength are limited in the range of vocations available to them.

These forms of "discrimination" are justified by the rational organization that is the U.S. military because 
they are based upon peoples' presumed ability (or lack thereof) to adequately function in organizational roles. In the case of military service, the inability to function in organizational roles could come at a very high cost the lives of members -- or in a worst-case scenario, the way of life for an entire nation. Thus these exclusions can be seen as forms of defensible, or functional, discrimination.

Yet historically, the U.S. military has chosen to discriminate against categories of people for reasons other than functional ones. The supposed impersonal nature of rational organizations is not manifest when the military resists the inclusion of people because of characteristics irrelevant to organizational function. Traits such as race, sex and sexual orientation are not specified as requirements for any particular military job, yet these traits have been used as criteria for excluding categories of people in part, or completely, from military service (see among others, Nalty 1986; Holm 1982; Shilts 1993)

Many of the historical and current patterns of discrimination against racial minorities, women and homosexuals was, and is, based upon the perceived inability of people in these categories to perform organizational functions (Department of Defense 1985; 
Steihm 1989), or their threat to organizational security (Wells-Petry 1993, p. 120). Yet many of the "inabilities" and "unsuitable" characteristics attributed to racial minorities, women, and homosexuals -- such as lack of intelligence, physical weakness, or moral depravity -- are shared by white male heterosexuals. Discrimination then must be justified in another way-- it becomes an effort to ensure social stability, even if the victims of the discrimination are perfectly capable of organizational performance.

\section{The Total Institution}

The U.S. military is a particularly restrictive form of bureaucracy-- a total institution. The total institution is described as an organization having characteristics which make it an all-encompassing influence in the lives of those who are its members. Erving Goffman outlined four traits which set total institutions apart from other organizations. First, members of the total institution eat, sleep and play in the same place, and under the same authority. Second, their activities are carried on in the presence of others, all of whom are treated alike, and are required to do the same things together. Third, the daily activities are tightly scheduled, with a sequence of activities being imposed by a system of explicit formal rulings and a body 
of officials. Finally, these enforced activities are part of a single plan designed to achieve the goals of the institution (Goffman 1961, p. 6).

Goffman further states that in total institutions, a split exists between a "large managed group" which he calls "inmates," and small supervisory staff. While the inmates live in the institution and have limited contact with anyone outside, the staff operate on an eight-hour day and are socially integrated into the outside world (1961, p. 7).

The U.S. military as a total institution differs from Goffman's model in that the "inmates" and "staff" are more nearly in the same situation. Although strict hierarchies exist within and between the officer and enlisted ranks, the fact remains that all service members have signed contracts which limit their life options. Because the military is a form of indentured servitude, no service member -- officer or enlisted -- has the option of simply quitting the job. All members have enlistment contracts which require that they serve a prescribed amount of time. All members are "inmates" of the institution.

The military diverges from Goffman's description in another important way: the amount of time a service member spends isolated from the outside world. Goffman's inmates are severely restricted in their interactions with 
outsiders, but military service members have varying amounts of time in contact with the outside. For example, submarine crewmen may spend months in only each other's presence, without even seeing the light of day, while a military recruiter may live in civilian housing and commute to an eight-hour day job just as civilians do.

Nonetheless, the military institution has the structural capacity to strictly regulate the lives of its members. Basic training is the most extreme example, wherein new recruits find that even their most minute behaviors are regulated: from their manner of speech and movement, to the particular ways they must dress and groom, to the times they may sleep or must wake. This type of indoctrination is designed to tear down recruits' individual identities, and force them to identify with the institution (Zurcher 1967).

Finally, the military has power over the very lives of service members. Particularly in times of war, the military may send service members on missions that will obviously result in casualties. Service members must follow the orders given to them or face disciplinary action ranging from verbal reprimand to execution.

This structural capacity for strict regulation of behavior, and the absolute power of life and death over its members makes conceptualizing the military as a 
"total" institution a useful approach. It does not matter how much regulation of behavior is actually imposed upon individual service members, or whether or not their lives are endangered. All service members must live with the reality that their lives may be disrupted at any time, that they may be forced by war or by other circumstances to move from "home" or be separated from family, forced to live in unfamiliar surroundings and required to work efficiently with unknown people. The only thing that matters to the institution is that its members can be made -- by force if necessary -- to perform their military function.

\section{Uniform code of Military Justice}

organizations have different levels of authority, and, therefore, may exercise different levels of coercion to control their members. The level of coercion that any formal organization may use to deal with its members is prescribed by state and federal laws. Organizations such as businesses and schools may use expulsion as their ultimate sanction. Other organizations, such as prisons or mental hospitals, may deprive members of their belongings or impose varying degrees of restriction of members' freedom of movement. While organizations may use their limited sanctions to deal with breaches of internal rules, in general only the federal or state governments 
may prosecute people for criminal offenses. The sole exception to this rule is the U.S. military. The U.S. military organization has the legal authority to try its members for criminal offenses.

The U.S. military is differentiated from other organizations by its legal system, based upon the Manual of Courts Martial (MCM), which contains the Uniform code of Military Justice (UCMJ). This body of law separates service members from many of the rights guaranteed civilians by the United states constitution. The rights to a trial by jury, and to post bail are forfeited. Written depositions may be introduced in non-capital cases, in contradiction of the defendant's right to confront witnesses. In fact, the supreme court has

...never to this day squarely held that a soldier has any constitutional rights when he is court-martialed, or indeed that he has any constitutional rights of any variety (Bishop 1974 , p. 114 ; gender in the original).

The U.S. military even has the power, when allowed by Congress, to conscript people into the organization against their will. Male civilians may be deprived of their constitutional rights guaranteed under the 13 th Amendment and forced into a form of indentured servitude-the military enlistment contract. once forced into the organization, they are then compelled to conform to organizational rules under threat of punishment. 
one argument suggests that the justice system in the military is not designed to provide justice at all, but rather to enforce discipline (Sherrill 1969, p. 67). The result is an uneven application of military law, whereby some innocent service members will be severely punished in order to set an example for others, and some guilty service members will not be prosecuted, if their trial could prove embarrassing to their command (West 1977, p. ix).

Service members are viewed as the property of their commanding officers (Sherrill 1969, p. 1). If a service member is accused of misconduct, the structure of the military court-martial allows great potential for miscarriage of justice. West (1977, p. ix) describes the initial process of forming the court-martial:

[The commanding officer] may refer the charges to trial by a court-martial convened by himself, or he may refer the charges to a higher commander with a recommendation for trial by that commander. In either event the officer who refers the case to trial by court-martial would appoint counsel for both sides as well as the court members (i.e., the jury) from the membership of his own command (gender in the original).

The UCMJ forbids unlawfully influencing the action of court (837 Art. 37). Yet the fact that a commanding officer has the authority to select court members from his own command leaves ample room for misuse of authority. officers who are familiar with one another are able to 
fathom what is expected or desired by officers higher up in the chain of command. Service members on trial can only hope that court members are motivated to achieve justice rather than to "save face" for the command or to protect their own careers.

\section{SUMMARY OF BACKGROUND}

The preceding discussion illustrates the bureaucratic model of organization and how the U.S. military fits this model. Further, it is argued that the military is a total institution-- an organization which has control over virtually all spheres of its members' lives. Finally, it is asserted that the military has unparalleled power -when compared to other total institutions -- to control the behaviors of its members, because it has the power to prosecute its members for criminal offenses.

Understanding the military's structural capability to control the behavior of its members makes the threats posed by their possible misbehavior appear less perilous. Yet the military continues to argue that internal threats are posed by the presence of certain categories of people. The following sections illustrate how the personalities of individual members, and attitudes of small groups or units may affect the organizational functioning of the military and other bureaucracies. This in turn may partially 
explain the military's exclusionary practices.

\section{THEORETICAL PERSPECTIVES}

\section{Introduction}

The bureaucratic model of organization stresses interdependence as one mechanism for ensuring functional cohesion between organizational units. Yet it is also clear that the personalities of those who work in bureaucracies may greatly affect the function of these organizations. Attention is focused here on micro-level issues of why people within organizational units choose (or refuse) to work together in a cohesive manner.

Sources of cohesion within and between groups of people may generally be described as fitting either one of two models: self-categorization, wherein people are described as identifying with one another because of "likeness" or shared experiences; or interdependence, wherein people are described as not necessarily feeling affection for each other, but needing each other to fulfill mutual goals (Turner 1987, pp. 19-26).

\section{Self-categorization}

A social group is conceptualized in selfcategorization theory as a "collection of individuals who perceive themselves to be members of the same social category....and apply the ingroup's norms of conduct to 
themselves" (Turner 1987, p. 101). This model suggests that there is an "attraction" between ingroup members which indicates intragroup cohesion.

The most-studied factor related to attraction has been similarity of group members, especially in terms of demographic factors such as socioeconomic status, education, occupation, age, race and gender (McGrath 1984, p. 187). This element of self-categorization theory suggests that merely being in the same race, sex, or other demographic category, and identifying with that category, is enough to generate ingroup cohesion.

This process of categorizing people produces and reflects stereotypes about members of groups. Groups are seen as desirable (ingroups), or undesirable (outgroups), based on the similarity (or dissimilarity) a person feels with a given group. The desire to obtain or retain ingroup membership encourages people to conform to ingroup norms and values. As Turner states, "[S]elfcategorization leads to stereotypical self-perception and... adherence to and expression of ingroup normative behavior" (1987, p. 102). A model of this type of cohesion (also called the primary group bond) is that found in family and friendship relationships.

The need to gain and retain the approval of the primary group is described by sherif (1964) in a study of 
group formation among boys in a summer camp:

(H) ierarchical ordering... is not the only dimension of group organization. Mutual liking also forms a pattern....

Thus, it can and does happen that individuals comply or conform in attitude and behavior to the organizational and normative system of their groups out of requirements of an inner voice (conscience), sense of loyalty, sense of responsibility, even sense of decency relative to follow [sic] members.... After all, fellow members are important persons in the individual's scheme of things, proportional to the importance of the group in providing support for his personal identity and as an instrumentality for fulfillment of his needs (pp. 264 and $271 ;$ gender in the original).

The power of self-categorical groups to compel conformity, then, is not only a reflection of a member's need to belong, but also a reflection of a member's need to define the self through group membership.

\section{Interdependence}

Self-categorization theory can be contrasted with interdependence theory, particularly that part which stresses functional unity. "Functional unity" refers to the satisfaction of group members' mutual needs, or mutual goals (Turner 1988, p. 20). This theory suggests that members need not like each other in order to function as a cohesive group, as long as they depend upon each other. This type of cohesion can be amplified in stressful situations. For example, when goal attainment is immediately important, group members become more cohesive 
(pull together) in order to achieve the goal (Johnson 1992, p. 203).

Further, Shaw (1976) hypothesizes that "...group cohesion increases the degree of social interaction, cooperation and influence between members" indicating that the degree of functional unity that exists between or among ingroup members may increase cohesion as members share more group experiences or perceive a common fate.

According to Janowitz (1959), cohesion based upon functional unity is the type of cohesion that is manifested by military service members. He states:

[I]t is not necessary to assume that cohesion in primary groups can only be the result of uniformity or like-mindedness among its members. To the contrary, a division of labor and a blending of perspectives can be the basis of group cohesion. What is crucial from the point of view of the military establishment is that the members of the smallest tactical units have gone through some trying group experiences which demonstrate to them the value of social solidarity (p. 66).

Bureaucratic organizations like the military, in this view, may find that cohesion among their members, especially at the small-unit level, is most easily generated through interdependence and the experience of working together successfully.

This interdependence-based cohesion is illustrated in Peter Bourne's (1970) study of members of an Army special Forces unit in vietnam: 
Except at times of actual attack, when group cooperation is imperative, open conflict among group members is commonplace. ...

Among the twelve team members a precarious and often changing balance of relationships exists. on the one hand, the shared danger of the external threat pushes them toward accepting cooperative membership in the group; at the same time, the all-important need of these men to confirm their self-reliance and independence... acts to force the group apart (pp. 114-115).

Bourne's study indicates that in fact, members of smallunits need not identify with one another at all. They need only to recognize that their jobs, if not their lives, depend upon other members of the group performing their group functions.

Self-categorization and interdependence theory are utilized in the following analysis to address some of the reasons that the military chooses to discriminate against groups of service members despite its bureaucratic organizational form and its unequalled power to control its members' behavior.

It is noted here that the self-categorization and interdependence models of group cohesion are similar to Emile Durkheim's mechanical and organic models of solidarity. Durkheim's concepts, however, are more generally applicable to community or cultural solidarity than to group behavior. Therefore the analysis is Iimited to the small-group models of cohesion. 
CHAPTER III

METHODOLOGY

\section{Introduction}

To those who must abide by them, regulations and laws governing the military are generally left unexplained. The opinions of service members regarding military policy are largely irrelevant; the willingness of service members to carry out their orders is all that matters. It is difficult, therefore, to infer from military regulations the specific reasons for discriminatory policies. In different historical periods, racial minorities, women, and homosexuals have all been perceived as threats to such things as "cohesion," "good order," "discipline," and "morale" (Binkin and Eitelberg 1982, p. 98; Goldman 1982, p. 252; Wells-Petry 1993, p. 91). The specific meaning that these concepts have, as they relate to military service, is not specified in the laws and regulations that affect these outgroups, nor is there any comprehensive explanation for why outgroups are viewed as disrupting forces in these areas.

It is a more simple task to go outside the military to ascertain exactly how the inclusion of outgroups could 
be construed as a threat to cohesion, good order, discipline, or morale. This may be accomplished in two ways: by examining the historical context giving rise to military policy and the proposed changes in it, and by examining stated reasons for the policies and the proposed changes in them.

In the following chapter the changes affecting each of three outgroups are put in historical and political contexts. Such background information provides greater understanding of each group's status in society and the evolution of their statuses in military service before the changes in laws or regulations that affect them occurred. The importance of social context is described by $c$. Wright Mills (1959, pp. 5-6):

The sociological imagination enables its possessor to understand the larger historical scene in terms of its meaning for the inner life and the external career of a variety of individuals. ...

The first fruit of this imagination -- and the first lesson of the social science that embodies it -- is the idea that the individual can understand his own experience and gauge his own fate only by locating himself within his period, that he can know his own chances in life only by becoming aware of those of all individuals in his circumstances. ...

The sociological imagination enables us to grasp history and biography and the relations between the two within society. That is its task and its promise (gender in original).

It is assumed that differing societal perceptions of the characteristics of these groups leads to different 
rationalizations for discriminating against them. Such perceptions might be illustrated by the different kinds of limitations placed on the military service of the three groups.

As mentioned above, the rationale for laws and regulations governing the military are generally left unexplained. Therefore, evidence that illustrates the arguments for or against the inclusion of outgroups in military service must be gathered elsewhere. The printed news medium is used in an attempt to expose the rationale behind military policy. Because it has fewer constraints than military policy-makers, the print news medium is free to publish more objective and in-depth analyses of the issue of discrimination in the military.

GENERAL METHODS

For the purpose of illustrating arguments for and against discriminatory policies, commentary from the New York Times was selected from the years during which laws and regulatory changes affecting each of the three groups were debated or enacted. This was accomplished by using the New York Times Index to find relevant articles and commentary concerning each group. The number of references selected for each case was limited by time-no more than a two-year window in which to choose articles 
for each group; or by number-- a maximum of 50 articles for each group (see the following sections for greater detail). These parameters were intended to place a limit on a virtually endless supply of data, and also to gather the "freshest" data-- those articles that were written during the heat of the debates.

\section{Racial Minorities}

President Harry S. Truman issued his Executive Order abolishing racial segregation in the military on July 26 , 1948. The New York Times Index was searched for articles pertaining to racial issues in the military for the year preceding the Executive order, and the year following it, creating a two-year window from July 26, 1947, to July 26, 1949. Within these dates, the Index was searched under the section of "US - Military Forces - General," for articles pertaining to racial issues. Within this section of the Index, the year 1949 contained the sub-heading Racial Equality Program, which was also searched, even though it did not appear in the previous year of the Index.

Rather than using a sample, all entries in the Index that mentioned racial issues in the military within the relevant time frame were included. This search yielded 31 articles, editorials, or letters which either focused on the issue of racial desegregation of the military, or 
mentioned it in discussions of other issues.

Women

The status of women in the U.S. military -- unlike that of blacks -- has undergone slow, incremental change over time. There is no single legislative or regulatory change that has had an affect similar to President Truman's Executive Order for racial desegregation. Therefore, for the purpose of gathering data, the New York Times Index was searched for appropriate entries surrounding March 22, 1979, the deadline originally set for ratification of the Equal Rights Amendment (ERA). Although the ERA was not specifically designed to change women's status within the military, it generated considerable debate over its possible effect on the services. Of particular concern was the possibility of women being subject to the draft, or of their being assigned combat roles.

The Equal Rights Amendment was sent by Congress to the states for ratification on March 22, 1972. At that time it had overwhelming popular support (Boles 1979), and seemed sure to be adopted well before the deadline of March 22, 1979. Yet in 1978, only 35 of the necessary 38 states had ratified the ERA, and four states had voted to rescind their earlier approval.

The opponents of the Equal Rights Amendment had 
proposed some politically damaging interpretations of the amendment. They asserted, among other things, that the ERA would force women to provide 50 percent of household income, wipe out sex segregation in reform schools, prisons and public rest rooms, and subject women to military conscription and to combat assignment.

Further, the eleventh-hour political efforts to ratify the ERA coincided with a national debate over whether or not draft registration should be reinstated, thus forcing an examination of women's changing role in the military. Finally, this date also coincided with a perceived foreign military threat-- the soviet invasion of Afghanistan.

The New York Times Index was searched under the section "United States Armament and Defense," subsection Women for entries concerning the possible conscription of women, or their assignment to combat duty.

Articles listed in these sections of the Index also pertained to such matters as the pregnancy of female service members, the dependency status of husbands, promotions, and unequal enlistment requirements for female in comparison to male service members. These issues were ignored, because they did not generate the type of emotional debate that surrounded the issues of draft status and combat assignments for women. In fact, the 
possibility that women would be subject to the draft and combat assignment is considered a major factor in the defeat of the ERA (Mansbridge 1990). Therefore, commentary were selected only if the Index made reference to combat assignments or the draft.

The search began with the original deadline date for the ratification of the ERA -- March 22, 1979 -- and worked forward and backward one day at a time until 50 appropriate entries were found. This method of searching produced a window from April 6, 1978 to March 7, 1980-350 days before and 350 days after the original March 22, 1979 ERA ratification deadiine. All of the Index references under the subsection women that included discussion of the draft or combat assignments were included in the analysis. These included news articles, editorials, letters to the editor, and New York Times Magazine stories.

Homosexuals

on July 16, 1993, the Pentagon, the Justice Department, the Joint Chiefs of staff, and President clinton finalized a compromise plan to allow homosexuals to serve in the U.S. military. The New York Times Index was searched for all mention of homosexuals, lesbians, or gays under the section "United states Armament and Defense" beginning on the date of the compromise, and 
searching forward and backward one day at a time until a total of 50 such references were found. This method of searching generated a window from May 28, 1993, to september 3, 1993-- 49 days before and 49 days after the July 16, 1993 announcement of the compromise plan. Again, rather than using a sample, all of the Index references to homosexuals in the military within the above time frame were used in the analysis. This included news articles, editorials, letters to the editor, photograph captions, New York Times Magazine stories, and one correction to previous commentary.

\section{CODING THE DATA}

\section{Overview}

An original assumption was that rationales supporting or opposing exclusionary military policies would revolve around small-group models of cohesion. This means that reasons given for the exclusion or acceptance of outgroups in military service would fit either the "interdependence" or "self-categorical" models of group cohesion, as discussed in chapter II. Yet the analysis of the data yielded a third, perhaps more important type of rationalization: the ideological argument.

The ideological argument flies in the face of both the bureaucratic model, which stresses meritocracy, 
impersonality, and the interdependence of organizational units, and small-group theories of interdependence and self-categorization. Ideological arguments stress abstract concepts of what "should be" rather than the more practical matters of human relations within a specific organization or group. A bureaucracy can determine, through standardized methods, who is best qualified to hold a particular position within the organization. Human interaction, whether viewed through the interdependence or self-categorization model of behavior, may also be directly observed. Yet ideology, though far more abstract, proves to be a powerful rationale both in favor of, and in opposition to changes in U.S. military policy. Ideological statements emerged from the data, and were, in fact, a very large part of the reformist stance. These statements, therefore, are included in addition to those fitting "interdependent" or "self-categorical" rationales for maintaining or reforming military policy.

This technique for developing categories for the data gathered in content analyses is described in Bruce $L$. Berg's (1989) summation of grounded theory:

The various categories researchers use in a content analysis can be determined inductively, deductively, or by some combination of both.... (A) $n$ inductive approach begins with the researchers "immersing" themselves in the documents (that is, the various messages) in order to identify the dimensions or themes that seem meaningful to the producers of each 
message. In a deductive approach, researchers use some categorical scheme suggested by a theoretical perspective, and the documents provide a means for assessing the hypothesis. In many circumstances, the relationship between a theoretical perspective and certain messages involves both inductive and deductive approaches. ...

The development of inductive categories allows researchers to Iink, or ground these categories to the data from which they derive (pp. 111-112, emphasis in original).

In this thesis, the deductive approach was used to draw the self-categorical and interdependent categories from the models of small-group cohesion. The ideological category was drawn inductively from the data gathered in the content analysis.

Besides the ideological argument, the data also yielded a number of statements which reflected Weber's (1946) bureaucratic model of organization. These made reference to individual merit or qualification for a job as criteria for assigning military personnel. These statements were included in another inductively formed category-- the bureaucratic rationale.

These four rationales for exclusion or reform -ideological, interdependence, self-categorical, and bureaucratic - were used as a framework for coding statements culled from the New York Times articles analyzed. They were cross-tabulated by the "reformist" or "exclusionist" stances implicit in the statements. The following table illustrates how the data were organized. 
TABLE X EXEMPLAR

STANCE TOWARD DISCRIMINATORY MILITARY POLICY BY RATIONALE

\begin{tabular}{||l|l|l|l|}
\multicolumn{1}{l|}{ RATIONALE } & SxAlusionist & Reformist & Total \\
\hline Ideological & & & \\
\hline Interdependence & & & \\
\hline Self-Categorical & & & \\
\hline Bureaucratic & & & \\
\hline Total & & & \\
\hline
\end{tabular}

These rationales for and against discriminatory policies in the U.S. military are first analyzed independently for each of the three groups: racial minorities, women and homosexuals. Then the distribution of statements are compared, contrasted and summarized in Chapter IV to illustrate the perceived similarities and differences between the three groups.

\section{Codes}

A content analysis of the Index references is done using individual statements, or parts of statements, as the unit of analysis. The themes of the articles themselves are ignored. This is because articles may include many statements, each of which may fit into a different category. In other words, a single article may contain several statements with stances both reformist and 
exclusionist, and rationales that are ideological, interdependent, and/or self-categorical in character. Therefore, the units of analysis are the individual statements within an article rather than the article as a whole. Note that because articles are not limited in the number of statements that may be used as data, tables in the analysis sections contain a much larger number of relevant statements than the total number of articles from which they came.

The following paragraphs describe the types of themes that would place statements into specific sub-categories. A reformist statement categorized as "ideological" in character would include references to justice, equality, civil rights, freedom, democracy, patriotism, religious principles (when the context supports reform), fairness, equal protection, and human dignity. Not included are the names of commissions or organizations that incorporate "ideological" language in their names. For example, the statement "this practice is contrary to the democratic way of life" is counted as an ideological statement, but the "President's Committee on Equality of Treatment and opportunity in the Armed Services" is not.

Exclusionist statements categorized as "ideological" include references to white supremacy (in a political context), communism, states' rights, traditional morality 
and religious ideals (when the context supports exclusion) and military tradition.

For both the reformist and exclusionist stances, "interdependent" statements would include references to unit efficiency or interdependence of jobs, or statements implying that one service member's welfare is contingent upon the competence of other service members.

statements with "self-categorical" themes found in reformist articles include references to the shared experiences of service members working together, the precedence of experiments in military desegregation (another type of shared experience) and other similar experiments, "progressive demonstration," education, and military indoctrination of all personnel, which is an attempt to instill identity based on military membership.

Statements with "self-categorical" themes found in exclusionist articles include references to group stereotypes, group loyalty, "friction" among service members (presumably based upon perceived differences), race and gender stereotyping and societal endorsement of racism and sexism.

It could be argued that some self-categorical stereotypes regarding the roles that people "should" assume (based on their categorical membership) are essentially statements of morality. However, morality- 
based themes have been coded as ideological rationales. The difference lies in the numbers of people addressed by the statement: that is, ideological rationales are statements that apply to all people, whereas selfcategorical rationales, even when they appear to be based on "morality," are directed at one category of people. Finally, for both the reformist and exclusionist stances, "bureaucratic" statements include references to individual merit, individual job qualification or fitness for duty, and military organizational goals and functions. Throughout the analysis sections in Chapter IV are direct quotes of relevant statements culled from the New York Times articles, which are underlined and used as illustrations of the rationales and stances discussed above. Rather than using the cumbersome parenthetical reference style to note the sources, a bracketed letter and number represent each article as listed in Appendix $A$. For example, the statement, women don't belong on the battlefield came from article [W16]: "Prospect of the Draft Gets a Mixed Reaction From Feminists," published January 25, 1980, as listed under the "Women" section of the New York Times articles listed Appendix A. The same abbreviated reference style is used for racial minorities [Rnn] and homosexuals [Hnn]. 
Inter-Rater Reliability

In order to assess the reliability of the coding instrument used, a Portland state University sociology graduate student familiar with research methodology was given a sample of the commentary analyzed, along with the coding rules and a code sheet. The sample included 20 articles selected from the New York Times Index. Analyzed for content, these articles yielded 82 statements which either supported or opposed discriminatory policies in the U.S. military, providing 82 possible matching points. The results indicate that of the 82 possible matching points, 76 were similarly classified. This provided an interrater reliability of .9268 or 93 percent, which was deemed adequate.

The following chapter is broken into three major subsections, with one each focusing on racial minorities, women and homosexuals. An extensive analysis of these groups is attempted, including historical, empirical, and political contexts of their experience with the United States military. 
CHAPTER IV

\section{FINDINGS AND ANALYSIS}

\section{RACIAL MINORITIES}

\section{Introduction}

Throughout its history, the United states military has been marked by varying degrees of racial segregation and discrimination. of immediate concern, however, is the situation of racial minorities in the U.S. military through the end of World War II, when their official status in the services was radically changed. on July 26 , 1948, President Harry S. Truman signed Executive order 9981, which decreed that the U.S. military would institute a new policy ensuring "...equality of treatment and opportunity for all persons in the Armed Services without regard to race, color, religion or national origin." The order had a profound affect upon the status of racial minorities in the United states, within the military, and more generally within the civilian population. Minority leaders viewed desegregation of the services as a step toward "...full participation in the benefits and responsibilities of American citizenship" (MacGregor 1981, p. 13) 
The term "racial minority," as used to describe U.S. military personnel, can be interpreted to mean any person who is not white/Caucasian. Until the Second World war segregation of minority races from whites, as much as possible, was the official military policy (DOD 1985). At different periods in U.S. military history, there have existed segregated units of African American, Japanese (Shibutani 1978), Native American (White 1990), Filipino (MacGregor 1982, p. 206), and Hispanic (DOD 1982) service members, to name a few.

However, literature on the subject of racial minorities in the U.S. military is largely limited to studies of the status and experiences of blacks. This seems logical for three reasons. First, blacks are currently the largest racial minority in the United States, so any study of racial minorities in the U.S. is likely to focus upon them. Second, within the military, the total number of other racial minorities combined is less than half the number of blacks (Binkin and Eitelberg 1982, p. 162). Third, the representation of other racial minorities in the military is more closely proportional to their numbers in the general population. Blacks constitute about 20 percent of the U.S. military (Young 1982, p. 227), a much larger representation than their 12 percent of the general population. 
The terms "minority" and "racial minority" as used here, are intended to include all people of color. The data, however, refer only to the situation of blacks in the military. Therefore the focus here is also upon the experiences of black service members.

Another caveat is pertinent at this point. Terms such as "colored" and "negro" appear in reference to blacks. These terms are not intended to cause offense or to indicate a lack of sensibility; rather they are cited as part of the historical context within which these terms were considered to be appropriate.

The following section, except where otherwise noted, it is a synopsis of blacks' history in the United states military as presented by the Department of Defense (1985).

\section{Historical Perspective}

Racial minorities have always been involved in the United states military. Blacks were allowed to participate, to varying degrees, in military service in the U.S. even before the American Revolution (Binkin and Eitelberg 1982, DOD 1985). Since then they have experienced various degrees of inclusion in the military, ranging from the participation of selected individuals, to limited group participation, to complete inclusion in the contemporary U.S. military.

The first use of blacks in military service in the 
U.S. was compelled by fear of "Indian" uprisings. During America's colonial period, native people were perceived as a threat to white settlers, so colonists felt compelled to organize militias for self-defense. The first legislation enacting a military organization was passed in 1607. The earliest laws made no reference to race as a criterion for membership or nonmembership in any militia. In the Northern colonies, free blacks were allowed to serve. But by 1639 , Virginia had passed a law excluding "negroes" from being provided with weapons. The use of blacks and "Indians" in the militia by other colonies was infrequent and on an individual basis. There was fear that arming blacks and training them to fight would increase the likelihood of slave revolts. As a result, blacks (usually only free blacks) were enlisted in large numbers in the colonial militias only when there was fear of imminent Indian uprisings. They functioned as laborers, scouts, and wagoners, but only rarely as combatants. Leadership roles were never open to blacks.

The exclusion of blacks from colonial militias had another, unintended effect. It gave blacks the same elevated social status as others who were exempt from service, including ministers and public officials. Colonial legislatures responded by requiring free blacks to work on public projects for as many days as whites 
contributed to military service.

In 1775, approximately 20 percent of the colonial population was black. Despite the colonists' desperate need for manpower for the Revolutionary War effort, black service in the military was still limited by whites' fears of slave uprisings. The British played on the divisive issue of slavery by offering freedom to "all indentured servants, Negroes, or others" (read: rebels) who would fight for the British side.

At first, the Continental Army did not allow the service of blacks, ordering recruiters not to enlist any "stroller, Negro, or vagabond." Yet despite the policy, blacks did serve. Early in the war, slaves sometimes took the place of their masters in military service (Binkin and Eitelberg 1982, p. 13). Eventually, a manpower shortage forced a change of policy. By 1778, Washington's army included 42 blacks serving with white soldiers on an integrated basis. By the end of the war, approximately 5,000 blacks had served in the Colonial Army of 300,000 .

In contrast to the Army, the Continental Navy, which from its very inception struggled with manpower shortages, placed no limits on the numbers of blacks who could enlist. A 1775 recruiting poster encouraged "able backed sailors, men white or black, to volil teer for naval service." No law barred blacks from naval service, and in 
fact, some blacks were paid bonuses for joining.

In 1792, after the Revolutionary war, Congress passed an act limiting militia service to "free able-bodied white male citizens." It would become a pattern to allow the service of blacks and other minorities only when manpower shortages made it necessary.

The Civil war gave blacks another chance to prove themselves in military service, but not at the beginning of the conflict. It was believed by many, including the President, that the purpose of the war was to preserve the Union rather than free the slaves (Frazier 1957, p. 107). President Lincoln, fearful that black Union soldiers might cause border states to join the Confederacy, barred the enlistment of black soldiers (Binkin and Eitelberg 1982, p. 13). But sagging enlistments again caused a change of policy in August of 1862. All-black regiments, with white officers, were formed. By May of 1863, the War Department was forced to create the Bureau of Colored Troops to handle the organization of black regiments for Federal service. From 1864 through the end of the war, blacks constituted 10 percent of the total Union Army force. These "colored troops" were frequently given the worst equipment and medical care, but they continued to serve with distinction.

The Union Navy, with its chronic shortage of 
manpower, began a more serious effort to enlist black sailors in 1861. There were no officially segregated units in the Union's navy, but blacks were relegated to lowly positions as servants, cooks, and powder boys. Blacks were never allowed to achieve officer or petty officer ranks, and were sometimes denied jobs such as "lookout," because it was believed that they lacked the necessary intelligence. But one black sailor, due to his courageous sea service, was appointed as an officer in the South Carolina militia after the war.

Blacks continued to serve during Reconstruction in troops maintaining political stability in the southern states. Their presence so outraged white southerners that the government eventually had to disband some black units, and move the rest to posts on the western frontier. Negative attitudes toward blacks remained despite the victory that freed them from slavery.

The years 1866 through 1890 saw westward expansion by mostly white settlers, despite the resistance of many of the native peoples. Black soldiers displayed such courage in campaigns against hostile Indian tribes that they earned the nickname "Buffalo Soldiers." Even though the Buffalo soldiers protected mail shipments, railroad construction, and settlers, white townspeople generally refused them any kind of service or respect. 
The brief Spanish-American War saw several volunteer black regiments with their own black officers. Military leaders were concerned, because blacks were still considered unfit for command. The issue became irrelevant, as the black-led troops arrived too late to see combat. But four regular-army black regiments, led by white officers, did see combat duty. White citizens did not know how to react to these returning black veterans. Some were celebrated as war heroes, while others were lynched by whites offended by their presence and status in the military.

World War I gave blacks little opportunity to prove their mettle in combat. Once again, questions about the abilities of black combatants were raised. The General Staff believed that the "poorer class of backwoods negro has not the mental stamina and moral sturdiness to put him in the line." Further, the military had no policy for the utilization of black units in the war, and the integration of units was never considered. The majority of black draftees were again relegated to jobs such as laborer and stevedore.

Blacks' chance to prove their ability to fight finally came in 1917, when the first black combat troops arrived in France. They were assigned to work under French command, and given French weapons and other 
equipment. They served with such distinction that members of the black regiment were awarded the croix de Guerre, or Legion of Honor, by France for their courage in action. In the years following world war I some in the war Department believed that blacks should not be allowed to serve in the military in peacetime. Reports by white officers alleged poor performance by black troops in combat. Charges of black cowardice were routine. War Department investigations pointed out poor leadership abilities of black officers. It was believed that black troops could function in combat, but only if led and motivated by white officers. When conscription began again in 1940, the military maintained a lower induction rate for blacks than for whites.

During World war II, nearly three-quarters of the blacks who served in the military were in the Army, typically as combat support personnel. Only 2.8 percent of combat units were black. Generalizations about the poor combat abilities of black soldiers were still widespread. While the civil Rights movement put pressure on the Army to end segregation, Army leaders argued that the service was not a laboratory for social experimentation. Yet, a kind of desegregation did occur during world War II. A German offensive in 1944 forced the Army to organize 2,500 black soldiers into separate 
platoons within white companies of the First and seventh Armies. These were the only "integrated" Army units in World War II.

Until 1942, blacks who were permitted to enlist in the Navy were restricted to the messman's branch. They were prohibited from going to sea, and were instead assigned to small boat stations, or stations ashore. As a result, very few blacks in the Navy ever saw combat duty. In 1943, two Navy vessels were assigned all-black crews. Their white petty officers were supposed to be replaced with blacks, but this was accomplished on only one of the vessels.

The Army Air Force held to the stereotype that blacks were not capable of performing in combat roles. However, blacks did eventually serve as airmen, by participating in a program designed to train civilian pilots, who could then be inducted into the service if needed. Named the "Tuskegee Experiment" for the airfield where black pilots trained, the implementation of black airmen in World war I proved very successful. It demonstrated once again that blacks could function in positions of authority, and in positions requiring a high level of technical training. The Tuskegee Experiment prompted the military, and in particular the Army Air Force, to question its policies on the use of black service members. 
Despite the historical pattern of excluding blacks as much as possible from military service, discussions by both black and white groups led to the conclusion that a more viable and cost-effective military force would result from equal opportunity within the services (DOD 1985, p. 38) and that only a desegregated military could move blacks toward "full participation in the benefits and responsibilities of American citizenship" (MacGregor 1981, p. 13.). These findings helped mitigate racist fears of military leaders, and gave President Harry S. Truman the grounds he needed to include racial desegregation of the military as a part of his 1948 message to Congress on the issue of Civil Rights.

The following sections analyze and discuss how public opinion and perception of racial desegregation of the military was reflected in the media in the years surrounding the order.

\section{Findings}

It is assumed that the positions of the U.S. military and the American public on the issue of racial desegregation in the military will be reflected in the news media. Articles found in the New York Times Index were culled for statements illustrating the arguments for and against efforts to desegregate the U.S. military, as discussed in Chapter III, "Methodology." 
statements or parts of statements found in the articles were categorized according to the stance they took toward racial desegregation. Two of the articles discussed racial issues in the military without mentioning the debate over desegregation at all. These two articles were not used in the analysis.

The exclusionist and reformist stances were then analyzed by the rationale they used to support their positions. These included all four of the rationales described in the previous chapter-- "ideological," "interdependent," "self-categorical," or "bureaucratic."

In Table I are summarized the data collected from 29 New York Times articles spanning the two-year period surrounding the Executive order that compelled the military to enforce racial desegregation. This summary includes only the contents of those articles which contained at least one statement that could be fit into one of the eight sub-categories. The articles yielded a total of 97 relevant statements. Two of the original 31 articles listed in the New York Times Index discussed race in the military without making any reference to desegregation, and therefore did not yield any useable data.

\section{Analysis}

The most notable pattern found in the New York Times 
articles analyzed in this section was an overwhelming support of President Truman's plan for racial desegregation of the military. Seventy-three percent of the statements culled from the New York Times articles contained themes that supported the reformist viewpoint.

TABLE I

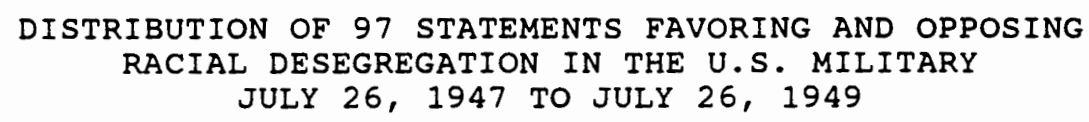

\begin{tabular}{|c|c|c|c|c|}
\hline \multirow[b]{2}{*}{ RATIONALE } & \multicolumn{2}{|c|}{ STANCE } & \multirow{2}{*}{\multicolumn{2}{|c|}{ Total }} \\
\hline & $\begin{array}{c}\text { Exclusionist } \\
n \quad(q)\end{array}$ & $\begin{array}{c}\text { Reformist } \\
n \quad(q)\end{array}$ & & \\
\hline Ideological & $6 \quad(6.2)$ & $57(58.8)$ & 63 & $(65.0)$ \\
\hline Interdependence & $6 \quad(6.2)$ & $0 \quad(0.0)$ & 6 & $(6.2)$ \\
\hline Self-Categorical & $10(10.3)$ & $7 \quad(7.2)$ & 17 & $(17.5)$ \\
\hline Bureaucratic & $4 \quad(4.1)$ & $7 \quad(7.2)$ & 11 & $(11.3)$ \\
\hline Total & $26 \quad(26.8)$ & $71(73.2)$ & 97 & $(100.0)$ \\
\hline
\end{tabular}

Almost 59 percent of the statements expressed specifically ideological reasons that the military should desegregate. Although ideological concepts do not explain how military service members would better interact with one another under desegregation, they have proved to be the most common arguments of reformists. The standard ideological argument of reformists is best illustrated by President Truman's message to congress on civil rights, delivered Feb 3, 1948 [R3]. Following is the part of Truman's message that dealt with the military. (Relevant statements are underlined.) 
During the recent war and in the years since its close, we have made much progress toward equality of opportunity in our Armed services without regard to race, color, religion or national origin. I have instructed the Secretary of Defense to take steps to have the remaining instances of discrimination in the Armed Services eliminated as rapidly as possible. ...

I have instructed the secretary of the Army to investigate the status of civil rights in the Panama Canal Zone with a view to eliminating such discrimination as may exist there. ...

The position of the United states in the world today makes it especially urgent that we adopt these measures to secure for all our people their essential rights.

This particular article yielded five statements classified as ideological in character, and supporting the reformist view of race in the military. No mention is made of threats to "cohesion," "discipline," "good order," or "morale." The problems of how service members will interact with one another, and how desegregation will affect the military are not addressed.

statements classified as ideological rationales in support of the exclusionist stance constituted 6.2 percent of the total number of statements. These were generally couched in the rhetoric of those who were afraid of (or angered by) desegregation. Some articles articulated the exclusionist stance by publishing statements criticizing it. For example, one article quotes a spokesman for The Committee Against Jim Crow in Military Training and Services accusing the Army and Navy of being "hopelessly 
bogged down in a tradition of segregation" [R12]. In this example, "military tradition," an exclusionist rationale, is criticized by a committee favoring reform. The same article reported that southern senators feel states' rights are usurped by this effort toward equality, while so-called southern extremists are accused of calling for white supremacy. Finally, Representative John E. Rankin of Mississippi asserted that both the Democratic and Republican stands on these issues were "communistic." This article [R12] alone produced four ideological statements illustrating the exclusionist point of view: military tradition, states' rights, white supremacy, and anti-communism.

Analysis of interdependent rationales yielded none that supported the reformist argument for desegregation. Again, 6.2 percent of the statements supported the exclusionist position. These cited threats to the efficiency of units, implying a threat to the interdependence of units. Quotes included references to impaired efficiency [R11], military expediency [R18], and questionable efficiency of the Negroes [R31] as reasons to maintain segregation. Each of these statements suggests that interdependence is at risk.

Self-categorical statements were employed in support of both exclusionist ( 10.3 percent) and reformist ( 7.2 
percent) stances. Exclusionist arguments that were classified as self-categorical in character included statements that desegregation would stir friction [R7], and impair morale [R11] within the services, and that it was unacceptable to the public, because it allegedly did not reflect the prevailing culture. As illustrated by statements attributed to Gen. Omar N. Bradley, "The Army will put men of different races in different companies. It will change that policy when the nation as a whole changes it" [R16]. The exclusionist preoccupation with local opinion, public opinion and community practices [R31] showed that people within and outside of the military believed that white and black service members were simply too different to risk the desegregation of the Armed Forces.

Reformists using the self-categorical rationale cited the precedence of desegregation in some Air Force units to support their side. "We had some mixed units in wartime, why not do it now?" asked New York Representative Adam C. Powell Jr, in a proposal to prohibit racial segregation in the Air Force [R7]. The statement reflects the shared experience that gives groups cohesion, according to selfcategorical theory. Other "reformist" statements cited such things as indoctrination, education, and progressive demonstration [R18], all suggesting that the experience of 
black and white service members working together would lead to acceptance of desegregation.

Finally, the bureaucratic model also supported exclusionist ( 4.1 percent) and reformist ( 7.2 percent) stances. Exclusionist arguments reflected Max Weber's bureaucratic model where it concerned organizational goals. Goals give organizations their purpose. The goal of the Armed Forces is to prevail in battle. Racial desegregation is viewed as a change in the military's goal-- from winning wars to conducting social experiments. Therefore racial desegregation is seen as a threat to the military organization. "The Army is not out to make any social reforms" [R16], stated the Army Chief of staff. This suggests that a change of goals to include social reform might fracture the military organization. Exclusionist arguments also included references to Army standards for enlistment, which required lower intelligence ratings than the other services. It was believed that these would encourage a disproportionately large number of Negroes to join the Army, and presumably cause disruption, because they had poorer educational opportunities (which is correlated with lower standardized test scores) before entering the service [R31]. Reformists cited individual merit and fitness for duty as criteria for military service, just as Max weber 
suggested in his bureaucratic model that members of an organization are rationally assigned to their "offices" based on merit rather than on social differences. One reformist argument stated that "any man, regardless of race, color, or creed who meets physical, mental or moral standards is qualified for enlistment" [R18]. Other statements supporting the reformist position included references to qualified individuals, qualified Negro students, individual merit and ability, and meeting prescribed standards for enlistment [R23] [R28].

Over all, the summary of the 97 statements regarding racial desegregation in the U.S. military (Table I) shows that the large majority of statements 73.2 percent, supported the reformist stance. Several factors might help account for these results. An examination of the possible explanations follows.

\section{The Political context}

When President Harry S. Truman signed the Executive order establishing equal opportunity for all races in the U.S. military, public opinion -- as reflected by articles in The New York Times -- was marked by indifference. Little debate on the issue was reflected in the media. Public opinion is shaped by political climate, and 1948 saw two major issues emerging that might have distracted the public from the issue of military desegregation. 
First, in July of 1948, people were becoming very active in the civil Rights movement. Black leaders, particularly members of the National Association for the Advancement of colored People, were calling for racial equality on all fronts of American life, not just in the military. Their movement had wide public support by both blacks and whites. Earlier in the year, president Truman had presented to the congress his proposals on civil rights. In addition to ending discrimination in the military, the proposals included strengthening existing civil rights statutes, preventing discrimination in employment and transportation facilities, providing federal protection against lynching and more adequately protecting the right to vote [R3]. Open hostility toward these civil rights proposals was largely limited to southern states.

Second, President Truman's Execuitive order to desegregate the military was only one of two orders that he gave on July 26, 1948. The other order instituted a fair employment practices policy throughout the civil branch of the federal government. The second order would have a more direct affect on the majority of U.S. citizens, most of whom were not in the military. The fact that the President gave two orders on the same day, and because military desegregation was only a part of a much 
more sweeping civil rights plan, the impact of desegregation in the military was largely diffused. This is illustrated in the New York Times articles that reveal little controversy on the issue of military desegregation.

\section{The Military context}

The military itself was dealing with several important issues during the decade in which President Truman gave his order to desegregate. First, the end of World War II forced the military to undergo rapid demobilization and significant downsizing. Further, two major branches of the U.S. military were in the process of being re-defined as the U.S. Army's "Army Air Force" became a separate service -- the U.S. Air Force -- in 1947. Then in 1948 when the Women's Armed Service Integration Act authorized women in the Regular Army, Navy, Air Force and Marines Corps, a plan for their use in the services had to be created. At the same time, several bodies of military law, including the Articles of War (Chapter II of the National Defense Act), were being revamped and consolidated into what would become (in 1951) the Uniform Code of Military Justice.

Finally, desegregation proved to be more costeffective than separating black and white troops. Under a policy of segregation, the military not only had to absorb the cost of separate units, but it also had to maintain 
separate recreational and other facilities. Desegregation then became simply a way to deal with inefficiency (MacGregor 1981, p. 614) rather than a way to address civil rights concerns.

The internal transformations that the military underwent in the late 1940s, like the political climate at that time, had the effect of diffusing the impact of racial desegregation of the services. Although some open opposition to the President's order did exist, particularly on the part of Army secretary Kenneth Royall, most of the services did, in fact, begin to implement plans for the use of minorities on a more equal basis. one notable point regarding the racial desegregation of the U.S. military is that it occurred several years before the 1954 Supreme Court decision Brown $v$. Board of Education of Topeka which deemed "separate but equal" policies of segregation as inherently unequal, and therefore unconstitutional. The military, in this case, lead civilian society in banning race-based discriminatory policies, although such discrimination is still a de facto part of both military and civilian societies.

WOMEN

\section{Introduction}

Examinations of military organizations throughout the 
world have always focused upon male service members, because women, even when included in military service, have traditionally been excluded from combat roles. Males routinely carried arms, but the arming of women was largely limited to states of siege (Rustad $1982, \mathrm{p} .5$ ). Therefore the military, as an androcentric institution, has ignored much of its history and depth of understanding where women's participation is concerned.

Military organization, besides having the manifest function of defending a society, has traditionally been an avenue for young men to demonstrate their masculinity. Women in a military organization, then, may be viewed by men as an unknown, or even an unnatural element, a factor which can disrupt the male bonding which sustains cohesion within small all-male units. For this reason (and others), the participation of women in the United States military, as in other militaries, has been sharply circumscribed.

A brief review of women's participation in the U.S. military through 1948, when the Women's Armed Service Act allowed women into the regular armed forces and combat exclusions were codified, is given below. However, the data gathered for analysis of attitudes toward women's participation are drawn from the period surrounding March 22, 1979, the deadine for ratification of the proposed 
Equal Rights Amendment to the U.S. Constitution. As discussed below, it was during this period that women's participation in the U.S. military came under extraordinarily intense scrutiny.

\section{Historical Perspective}

Women's participation in the continental Army of the Revolutionary War was largely limited to such support duties as cooking, sewing, cleaning laundry, washing bandages, and tending the wounds of male combatants. They did not directly participate in armed conflict except under the most extreme circumstances. For example, when members of an artillery crew were wounded and unable to fire their weapon, "Molly Pitcher," the wife of a soldier, cleaned, loaded and fired the weapon until a relief crew arrived. The true identity of Molly pitcher is in dispute, but her actions on the field of battle were not unusual. Women had opportunities to engage in some combat activities, simply because they were closely attending to men in combat conditions.

During the 18th and 19th centuries, women were routinely present with the armies in battle. Indeed, with the constant notorious manpower shortages, sustaining Washington's army in field or in garrison would have been next to impossible without the women. Moreover, it was common and accepted practice for poor but respectable wives, mothers and even daughters, to go along with their men when they went off with the army; often they had no other practical alternative. ... 
The women's civilian status did not shield them from the grit, grime, and hardships, nor did their lack of military training protect them from the horrors of war and the personal risks they faced in the daily performance of their assigned tasks (Holm 1982, p. 4).

While women were not allowed to officially participate in U.S. military actions prior to the spanishAmerican War, some women would go to extraordinary lengths to serve. Some wanted to join their husbands or loved ones on the battle front, while others were more interested in joining the fight. There are several known cases of women disguising themselves as men in order to serve as soldiers. Of these, the best known are Deborah Sampson, who served for three years in the continental Army as "Robert Shirtliffe" before being discovered; Lucy Brewer, the "first girl marine," who served for three years aboard the USS Constitution as "George Baker" in the War of 1812; and Loretta Velasquez who served in the Civil War and fought in the Battle of Bull Run as "Lt. Harry $T$. Buford" (Holm 1982, p. 5; Rustad 1982, p. 19). Estimates of the number of women who disguised themselves as men and served on either side of the civil war are as high as four hundred (Holm 1982, p. 6)

The greater and greater lethal power of weapons in the civil war brought a critical need for professional medical care in the field. Women who tended the wounds of soldiers had once been viewed as nothing more than camp- 
following prostitutes, but, out of necessity, the military began to recruit more highly trained nurses, whose status matured into a patriotic professionalism. In 1901, the Spanish-American War brought women their first formal support role in the U.S. military: the Army Nurse Corp. The field of nursing gave legitimacy to women's participation, and eventually would lead to their expanding roles in the U.S. military (Rustad 1982, p. 21). The First world War brought to the U.S. military a huge shortage of telephone operators, administrators, and clerical workers. In order to fulfill the need, the Department of the Navy, in March of 1917, authorized the inclusion of women in the Navy Reserve as yeomen, radiomen and other essential ratings. This allowed the Navy to avoid critical manpower shortages, and to free up men for combat duty. The Marine corps later followed suit, but the War Department was reluctant to allow women to serve in the Army in any capacity other than nursing. At the war's end, more than 34,000 women had served in the U.S. Army and Navy Nurse Corps, the Navy, the Marines, and the Coast Guard (Holm 1982, p.10).

The disparities between the services in the levels of women's participation is a reflection of the prejudices of the male service secretaries, illustrating again how such prejudices can lead to institutionalized discrimination: 
Although all the services were working within essentially the same legal constraints, the critical element of difference between the decisions of the Navy and those of the Army on enlisting women was the attitudes of the two service secretaries. The Navy Secretary saw the need for military women, and, if he had reservations, he overcame them; the secretary of War was unalterably opposed to the idea and would not concede the need despite overwhelming evidence to the contrary.

Had the war continued much longer, the manpower crunch, coupled with pressures from his commanders... might have forced the secretary of War to capitulate. But the war ended in November 1918, and the subject was shelved with an official sigh of relief (Holm 1982, p. 14).

Because the United states did not have to contend with personnel shortages as critical as those faced by European nations during the First World War, women's roles in the U.S. military closely followed their gender role expectations. Their participation was limited to "women's work" within the male-dominated military. During the period of military drawdown at the war's end, women were the first to be discharged from the services. At home they were the first to lose their male-dominated civilian jobs when men returned from the war (Rustad 1982, p. 25). During World War II and the following decade opportunities for women in the military greatly expanded. In May of 1942, the Women's Army Auxiliary Corps (WAAC) was created, and in July of 1943, the first WAAC battalion, composed of 555 women, was sent overseas for duty. The WAAC gave women only limited military status, 
but in september of 1943 it was replaced by the Women's Army corps (WAC), which gave women full military status and benefits (Rustad 1982, p. 28). Women also worked with the Navy as Women Accepted for Voluntary Emergency service (WAVES); the coast Guard as SPARS (a contraction of the Coast Guard motto, "Semper Paratus," -- Always Ready); and in the Marine corps Women's Reserve. Women in the Air Force (WAF) was formed in 1947, when the Air Force became a separate service.

Despite women's greatly increased participation in the military during World War II, they faced a lack of acceptance of their military role by both military men and civilians. When the media examined women's participation in the WAC, the focus was on such trivial matters as girdles, whether or not women would salute, and whether or not they would march. Men's opinions of women in the services generally fit one of two stereotypes: that of the whore or the lesbian. Jealous wives of soldiers and other civilian women resented WACs as possible competition for men. Political and religious fanatics could not accept the idea that women could be any place other than the home (Rustad 1982, p. 30-31).

Within days of the end of World War II, the Army forced the WAC to dismiss 98 percent of its members (Rustad 1982, p. 34), and women's familiar pattern of 
disposable service in the military and civilian job sectors began again. It appeared that women's inclusion in the services was based not on a desire to establish equal rights and opportunities for women, but rather a simple attempt to address personnel shortages within the services.

In June of 1948, Congress passed the Women's Armed Services Act of 1948 (Public Law 625). The Act gave women a permanent place in the regular and reserve Army, Navy, Marines and Air Force of the United States, with full military status and benefits. However, it limited the numbers of women to two percent of the total force, and also limited women's attainable rank. Further, the new law maintained the Women's Army corps as a separate organization within the Army. Army women who were not members of the Nurse or Women's Medical Specialist Corps were required to be members of the WAC. The other services had no such stipulations.

Most important, however, was the exclusion of women from combat assignments. The combat exclusion, as the key stipulation to allowing women to serve in the regular forces, was codified in federal law. The Air Force prohibited "female members of the Air Force [from being] assigned to duty in aircraft engaged in combat missions" (United States Codes, title 10, section 8549); while the 
Navy and Marine corps stipulated that

women may not be assigned to duty on vessels or in aircraft that are engaged in combat missions, nor may they be assigned to other than temporary duty vessels of the Navy... not expected to be assigned combat missions (United states codes, title 10, section 6015).

No law barred women from being assigned combat duty in the Army because the WAC had its own regulations which prohibited women from filling combat roles. The Army drafted its own combat exclusion policy in 1979 when the WAC was dissolved and women were allowed into a desegregated Army.

The rank and number limits had the effect of discouraging women from enlisting in the military services, and preventing women from gaining power or prestige once they were in. Because they were denied combat assignment, "women were, for all practical purposes, automatically excluded from participation in the primary mission of the armed forces, and their secondclass status was thus assured" (Holm 1982, p. 127).

In 1967, a new law repealed the two percent limit and allowed for the advancement of women into the ranks of senior officer. The restrictions on combat duty, however, remained.

The different codes and regulations, and different definitions of "combat role" between the services has led to many inconsistencies and contradictions: A 1989 
examination of women's role in the armed forces showed that the Air Force and Army had opened their heavyengineering units to women, but the Navy had not, saying engineering crews work too closely with combat forces. The Navy allowed women to fly fighter planes as instructors, while the Air Force did not (Moore 1989). The Coast Guard allowed women to serve on any of its aircraft or vessels, some of which would have combat roles under the aegis of the Navy in times of war, while the Navy continued to bar women from service on all Navy combat ships.

The importance of the combat exclusion is illustrated by the Supreme Court's 1981 decision to exclude women from the draft, reasoning that because the draft is used to bring combat troops into the armed services in times of war, there was no reason to apply it to women.

The combat exclusion would remain intact until 1993, when it was altered by the Secretary of Defense. Women may now be assigned to combat aircraft and ships, although the service secretaries are not required to make such assignments. Despite these changes, combat exclusions still cover such service occupations as armor, field or air defense artillery units, infantry units, and a variety of combat support units.

The following sections analyze and discuss how public 
opinion and perception of the possibilities that women might be subjected to the draft or to combat are reflected in the media in the years surrounding the defeat of the Equal Rights Amendment.

\section{Findings}

Summarized in Table II are the data collected from 50 New York Times articles listed within a 700-day window surrounding March 22, 1979, the original deadline for passage of the Equal Rights Amendment. The New York Times Index listings were searched backward and forward from March 22, 1979 one day at a time until the 50 appropriate entries were found. This method of searching produced a window of time from April 6, 1978 to March 7, 1980, 350 days before and 350 days after the original March 22, 1979 ERA ratification deadline. Eight articles mentioned the issues of women and the draft, and/or women in combat without making any statements either in support or opposition. The content analysis of the remaining 42 articles yielded 203 statements which could be classified as rationales supporting or opposing the drafting of women and their use in military combat roles.

\section{Analysis}

Unlike the question of racial desegregation, which produced an overwhelming number of "reformist" statements, 
the issue of subjecting women to the draft or to combat produced a more evenly divided set of statements.

TABLE II

DISTRIBUTION OF 203 STATEMENTS IN FAVOR OF, AND OPPOSITION TO SUBJECTING WOMEN TO COMBAT DUTY AND/OR THE DRAFT

IN THE UNITED STATES MIIITARY

APRIL 6, 1978 TO MARCH 7, 1980

\begin{tabular}{|c|c|c|c|c|}
\hline \multirow[b]{2}{*}{ RATIONALE } & \multicolumn{2}{|c|}{ STANCE } & \multirow{2}{*}{\multicolumn{2}{|c|}{$n^{\text {Total }}(8)$}} \\
\hline & $\begin{array}{c}\text { Exclusionist } \\
n \quad(8)\end{array}$ & $\begin{array}{c}\text { Reformist } \\
n \quad(8)\end{array}$ & & \\
\hline Ideological & $14 \quad(6.9)$ & $70 \quad(34.5)$ & 84 & $(41.4)$ \\
\hline Interdependence & $2 \quad(1.0)$ & $0 \quad(0.0)$ & 2 & $(1.0)$ \\
\hline Self-Categorical & $40(19.7)$ & $3 \quad(1.5)$ & 43 & $(21.2)$ \\
\hline Bureaucratic & $49(24.1)$ & $25(12.3)$ & 74 & $(36.4)$ \\
\hline Total & $105(51.7)$ & $98(48.3)$ & 203 & $(100.0)$ \\
\hline
\end{tabular}

Slightly less than half ( 48.3 percent) of the statements could be classified as reformist. However, the largest single category of statements, which constituted 34.5 percent of the total, were ideological arguments supporting the reformist stance. These cited such things as equal rights of women [W1], and women's sharing of responsibility for helping with national defense [W31] as reasons that women should be subject to the draft and allowed to serve in combat duty. These "rights and responsibilities" regarding the military are viewed as the route to fair treatment of women in civilian society as well:

Omission from the registration and the draft ultimately robs women of the right to firstclass citizenship and paves the way to 
underpaying women all the remaining days of [their] lives [W44].

Further, it is suggested that a male-only draft actually violates the constitutional rights of men, by placing an unfair share of risk upon them [W44].

A much smaller number of statements, 6.9 percent of the total, supported the exclusionist stance with the ideological rationale. Ideological statements supporting the exclusionist position cited such things as traditional morality and religious ideals [W35] as reasons to bar women from the draft and combat. One suggested that an all-inclusive military would force women to submit to "... men who merely wish to exploit women with ever more brutal efficiency" [W3]. Another exclusionist position even suggested that the President's call to register women for the draft would actually suppress their attempts to gain equal rights:

[I]n calling for the registration of women for military service, [President] Carter has not only hurt the chances of any draft for national service, but also postponed, if he has not defeated, the Equal Rights Amendment to the Constitution [W36].

The reformist stance employed very few arguments classified within the small group concepts of interdependence or self-categorical models of group cohesion. Reformist arguments included no "interdependence" statements at all in support of the idea 
of greater involvement of women in the military, and employed only three statements, 1.5 percent of the total, that could be classified as self-categorical. These included references to increased military group loyalty when women are included in the draft [W4], the precedence of World War II and Vietnam where women served in combat [W31], and again more shared identity derived from the experience with women as spies, saboteurs, and assault troops [W39].

The exclusionist stance was supported by only two statements ( 1 percent of the total) classified as the interdependent rationale, both citing threats to combat effectiveness if women were included in fighting units [W39]. However 40 statements could be classified as selfcategorical, many more than employed by the reformist stance. Exclusionist statements cited mostly gender role expectations as reasons not to include women in the draft or combat. Statements that parents do not raise their girls to be soldiers [W4], that combat is no job for a young lady [W10], that women don't belong on the battle field [W16], that the military should be prevented from taking our women folk [W38], and that suggestions to conscript and assign women to combat roles stabbed American womanhood in the back [W31] were typical rationalizations for excluding women from expanded roles 
in the military. These rationalizations viewed the draft and combat as an affront to "womanhood," or femininity. other self-categorical arguments viewed women's military participation as an affront to the masculinity of male service members. Typical statements referred to male service members' hostility toward women, and men's sense of superior masculinity [W39], which would be threatened by the presence of armed female soldiers. Other statements cited the chivalrous impulse of men toward women [W15], the social proscription that men must protect and defend women [W3], and the disruptions which might occur because men and women in the services might be attracted to each other [W2]. One revealing argument is the idea that the military builds men and is an important agent of socialization and enhancement of young men [W3], which, by default, must mean that women and feminine traits do not belong in the military.

The most frequent self-categorical argument employed by the exclusionist position, then, appears to revolve around supposedly intractable differences between gender roles, and in particular, a perceived threat to masculinity. Placating male service members then becomes very important, because the creation of a sense of manliness is viewed as a meaningful benefit of military service: 
One purpose of military training is to reduce individual differences and to make men as nearly as possible into replaceable units. A soldier's compensation for his loss of individuality is in participating in a group identity-- and the more specific that identity, the more compelling.

To draft women is necessarily to diffuse this collective identity-- to change the very idea of what a soldier is.

In the absence of a national emergency that would bind soldiers and civilians, men and women, together in a common purpose, the drafting of women takes away whatever fun there is in being a soldier [W39].

The bureaucratic rationale was employed by both the reformist and exclusionist stances. Twenty-four percent of the total number of statements were classified as using the bureaucratic rationale to support the exclusionist stance. This accounted for the largest number of statements supporting the exclusionist stance. Many of these cited physiological differences between men and women, which supposedly made men more individually qualified for combat roles. Statements included assertions that biological differences between the sexes made men more aggressive, competitive, risk-taking, indeed more combative, than women [W3]. Men were given credit for having greater aptitude for group leadership than women $[\mathrm{W} 3]$. Other statements raised questions of women's capability [W9], women's lack of physical strength and their "...problems every month" [W32]. Finally, citing a larger organizational context, statements suggested that the military had no need to draft women, that registering 
women was unnecessary and economically unjustified because no manpower shortages existed [W50], and that the conscription of women had no military justification [W41], especially given the then-current ban on women filling combat roles.

The bureaucratic rationale accounted for fewer statements in support of the reformist stance. Twentyfive "bureaucratic" statements, constituting only 12.3 percent of the total, supported the reformist position. These statements asserted that no distinction could be made between women and men based on ability or performance [W29] and that individual ability is a more important factor for determining competence than sex roles [WI]. Bureaucratic statements further asserted that women offered a greater reservoir of quality recruits than the male population [W1], and that women service members were better educated and accounted for less lost time than men [w30]. Finally, statements suggested that the military needed the flexibility made possible by expanding women's roles [W10], and that doing so would save money [WI].

In summary, the 203 statements regarding the possible conscription and assignment of women to combat roles in the U.S. military (Table II) appeared to slightly favor the discriminatory military policy. The data show that a marginally greater number of statements, 51.7 percent, 
supported the exclusionist position. Factors which might help account for these results are outlined in the following sections.

\section{The Political context}

The March 22, 1979 deadline for the ratification of the Equal Rights Amendment, besides generating debate on women's rights in American society, also had the effect of focusing public scrutiny on the situation of women in the United states military. Proponents of the ERA generally took the position that equal rights for women required accepting equal responsibility for national defense, including the possibility of conscription and combat assignment for women. That principle may have destroyed any chance the ERA had for ratification (Mansbridge 1990). As one antiratificationist pamphlet warned readers, "Watch out, they're going to draft your daughter!" (Mathews and DeHart 1990, p. 137).

The status of women in the military became a microcosm of their status in society, as the Equal Rights Amendment was demonized by opponents as an attack on "womanhood." The possibility of drafting women and assigning them to combat was a rallying point also for the proratification side, who hoped to push the ongoing "gender revolution" to its natural conclusion, equal rights for the sexes. 
It is true that the dissonance between traditional womanhood and woman warriors made the draft-combat issue the most damaging of those raised by the opposition [to the ERA] . ... The anomaly of women warriors was too powerful for the opponents to surrender no matter what the facts. As for proponents, the gender revolution made it virtually impossible for them to have hidden from the logic of their position even if they had wanted to do so (Mathews and DeHart 1990, p. 140).

The cold War shaped many military policy-making decisions in the years surrounding March 22, 1979. The national attention given to the status of women in the military was further intensified by international political factors, which made the danger to U.S. military women seem more real and immediate.

First, President Carter, in his January 1980 state of the Union Address, had proposed reinstating the draft for men, and possibly women, as a response to the soviet invasion of Afghanistan. This invasion, the Soviet Union's first attack on an independent nation outside of the Warsaw Pact since World War II, was seen as a threat to the United States' vital interests, including Persian Gulf oil resources. Second, in september of 1979, rumors of a Soviet combat brigade stationed in Cuba led the U.S. government to believe that the Russians had "several thousand troops less than 100 miles from our shores" [W8], a rumor which eventually proved false [W49]. Finally, the rise of Islamic militancy, especially in Iran, was 
perceived as yet another potential military threat from abroad, both to Persian Gulf oil supplies and as a possible terrorist menace.

The general fear of the soviet military superpower during the cold war, combined with foreign military excursions, generated real fear in the United states that the U.S. military might be pulled into an overseas conflict, and that U.S. military personnel, both male and female, could face combat situations. Public opinion on these issues was important for two reasons. First because public opinion "affects the decisions of elected officials and second, because it affects public support for the military" (Stiehm 1989, p. 189). Public opinion, as measured by statements culled from the New York Times, suggests that the American public was divided on the issue of subjecting women to military conscription and to combat assignments.

\section{The Military Context}

The problems for the United states military in the years surrounding March 22, 1979 were twofold. First, the military was generally unpopular. The vietnam war had given the U.S. military its first ever defeat. The war had been protracted and highly unpopular, both in the military and in civilian society. Rather than the celebrations following World War I and World War II, or 
the indifference following the Korean War, service members returning home from vietnam faced ridicule and hostility. Male service members were accused of being baby-killers and drug addicts, while the morals of women service members were called into question, to the point that it was believed by some that they had participated in the war merely to "service the troops." The hostile attitude toward the post-Vietnam military added credence to the idea that "good" women did not belong there.

Second, the discontinuation of the draft in 1972, and the beginning of the all-volunteer force in 1973 left the military with potentially severe manpower shortages. The House Armed Services committee believed that the allvolunteer military forces had "failed to meet the nation's needs," and that it was necessary to resume registration to create a bigger pool of potential draftees for the Selective Service system [W8]. Because the reinstatement of the draft (for males) seemed inevitable, the greater question became the issue of whether or not to include women in the draft. A practical argument against including women in the draft was the simple fact that they were legally prevented from serving in combat roles, and filling requirements for personnel in combat roles was the usual reason for conscription. Therefore, contemplating women's subjection to the draft necessarily meant 
rethinking their use for possible combat assignment.

The practical argument in favor of including women in the draft was the question of the constitutionality of a male-only draft. This challenge might come from men who resented being singled out for military servitude, or from women who resented being excluded from the career opportunities available to military service members. White House officials believed that a lawsuit "challenging the male-only program as unconstitutional could be successful in blocking the whole program" [W40], a contingency that could further erode military readiness.

Reports on the use of women in the military suggested that "the female population offered a 'greater reservoir of quality recruits than the male population' and that greater utilization of women would save money for the military" [W1]. This indicated a practical advantage to women's inclusion in the draft. Proponents of the Equal Rights Amendment summed up the expected impact of the ERA on women's status in the military as such:

It was intended that women be allowed to volunteer for military service on the same basis as do men. It is likely that both men and women who meet the physical and other requirements, and who are not exempt or deferred by law, would be subject to conscription, if a draft law is in force, and would be assigned to various duties (including combat) depending on their qualifications and the service's needs.... Responding to fears that mothers would be taken from their children into military service under the ERA, supporters in Congress noted that 
Congress would retain ample power to create legitimate sex-neutral exemptions from compulsory service (e.g., exempting both male and female parents with children under eighteen years of age [Boles 1979, p. 34, emphasis in original]).

This expected impact of the ERA may have sounded like a completely new concept for the use of women in the U.S. military. However, prior to the end of World War II, Congress was in fact quietly beginning the "process of enacting a law to draft unmarried, unemployed women into the services as being more logical than drafting men away from their families" [W16]. During the prolonged European conflict, the practical need to deal with personnel shortages overcame any reluctance to subjecting women to the draft. One conclusion that might be drawn is that the gender-role-based reluctance to subject women to the draft and combat assignment can only be overcome by the most severe of circumstances, the widespread belief that the very existence of America is at stake.

\section{A Feminist Perspective}

To a large extent, exclusionist arguments that are self-categorical in character rely on arcane, immeasurable ideas about the nature of males and females, and their "natural" relationship to each other. It may well boil down to the belief that combat is not "lady-like," or that engaging in combat is a distinctly male responsibility. 
In this case, the very definition of femininity is associated with the need to be protected, and, conversely, masculinity is associated with the male's ability to provide that protection. As explained by Rogan (1981, pp. 296-297) in a study of women in the U.S. Army:

Male soldiers have always thought of women as small and weak, the people whom wars are fought to protect. Female deaths in combat imply a failure to protect, and therefore a failure of masculinity. The combat debate is so fierce not because of reluctance to expose women to the enemy but because men do not want women on their own side. The problem is not women's incapability. It is a problem of men's incapability if women are beside them, even leading them, particularly when women are armed aggressors. ... Women soldiers deprive men of their masculinity by showing that soldiering is not so terribly hard and by usurping the profession. This is why men... insist on the need to protect women. This is why they emphasize physical toughness and combat. This is why they would rather protect women than teach them to protect themselves or to protect men (emphasis in original).

The obvious conclusion that can be arawn is that men do not protect women for women's benefit, or for the benefit of society as a whole, but to reinforce their own superior status within society. The feminist concept of "the pedestal" becomes relevant here. Men, including military men, supposedly "worship" women, and protect them by putting them on "the pedestal," only to react with vengeance if women do not wish to stay there. (Note here that "the pedestal" is more accessible to white women than to women of color, who are less valued and face unique 
forms of prejudice.) Rogan's point is reinforced by a remarkably similar observation made by stiehm (1981, p. 292 ) in a study of women in the Air Force Academy:

Is it not possible that men's aversion to women's suffering is based on their feeling that a suffering woman implies men's failure to be protective? Thus the pain men feel may derive not from sympathy but from a feeling of failure.... The fact, of course, is that in war men on both sides terribly and regularly hurt women on the other side. Half the victims in any war are "noncombatants"-- largely women, children and the elderly. Quite obviously, a desire to avoid hurting women does not control men's behavior. At best, men do not want "their" women hurt. In fact men do not object to having women in combat so much as they object to having women on their side. This is important. It means that even if some women are physically able and are so moved by logic or their sense of justice as to insist upon sharing war's risk, their offer will probably be refused. Men do not want women's assistance in the waging of war (emphasis in original).

The preceding commentary illustrates two points asserted by the feminist perspective. First, women are viewed as property of the men responsible for protecting them, and following this premise, military men use the rape and murder of women who "belong" to the enemy as a tool to assert their domination over enemy males. Second, women in combat are a threat to male service members because they are a threat to masculinity. Perhaps, from the male perspective, military service proves men's toughness and masculinity, and therefore any feminine traits exhibited by service members (male or female) are despised. This 
attitude is evidenced in the standard cry of the military basic training drill instructor attempting to motivate his men: "You ladies look like shit!" In this case, the first "expletive" is intended to be far more devastating than the second.

Further, there is a fundamental contradiction in feminist positions which could also be interpreted as threatening. Feminist philosophy is vehemently opposed to organized violence, which is perceived as a patriarchal tool of oppression. Yet organized violence is the very purpose of a military. Therefore, it may be argued that the inclusion of women in military conscription and combat assignments would be in opposition to feminism, whatever its affect on women's status in the military.

Finally there may be a perceived threat to military readiness, as the inclusion of large numbers of "feminist" service members (read: women) threatens to "pacify" the military establishment. These last points are well

illustrated by Reardon (1985, p. 55-56):

The equal right to serve in the military has been viewed by some, even feminists, as a major step forward. However, it also should be noted that the issue has raised profound controversy among women's groups. The traditional peace organizations feel that women's resistance to military service is a form of struggle against war and militarism. Still others believe that the presence of women in the military could serve to mitigate the savagery of warfare and contribute to some prudence in decisions to use armed forces-- the presumption being that more 
restraint will be applied if the forces are made up equally of women and men. ... (c) onscription of women into the military and into combat forces would help to erode militarism and limit the occurrence of warfare.

This perceived fundamental contradiction between what is "feminist" and what is "feminine" may lie at the center of the controversy over women's status in the United states military. A similar objection to the participation of homosexuals in the military becomes evident in the following section.

\section{HOMOSEXUALS}

\section{Introduction}

A unique difficulty is involved in any attempt to examine the participation of homosexuals in the United states military. Unlike racial minorities and women, homosexuals are an invisible outgroup. Accounts of their service are largely anecdotal in nature, because a public admission of homosexuality is, and has usually been, grounds for discharge. The U.S. military gathers no official statistics regarding homosexuals for the purposes of comparative studies of service members, as is done for racial minorities and women. The only official statistics involve separations from service (voluntary or otherwise) for the "offense" of homosexuality. Between 1980 and 1991 such separations numbered nearly 17,000 (RAND 1993, p. 8), 
and cost the military hundreds of millions of dollars (Shilts 1993, p. 4).

Despite President Clinton's 1993 compromise which allowed homosexuals to serve in the military so long as they kept their sexual orientation secret, legal proscriptions against homosexual acts by service members still exist (UCMJ art. 125), and the official Department of Defense policy remains that "homosexuality is incompatible with military service" (DOD 1982). Therefore, homosexual service members who wish to remain in the military must hide their sexual orientation in order to avoid discharge. As a result, measuring their participation, or even their presence in the military, involves much speculation, and is typically accomplished only after homosexual service members have separated from the services.

Another problem involves the definition of "a homosexual." The word may be simply defined by conduct-that is, any service member who engages in a "homosexual act" (observable behavior) could be labeled a homosexual. The military, however, carries the definition further-- to include people who allegedly have "homosexual tendencies" (Army Regulation [AR] 600-443, 1950), regardless of their actual behavior. This definition attempts to reach into the minds and hearts of service members for unmeasurable 
"evidence" which might prove them incompatible with military service.

Such characteristics as race and sex are generally confirmed with a glance at the surface features of people, but "confirming" sexual orientation, by necessity, must be done in other ways. These have included gathering incriminating statements from suspect service members, their families, friends, co-workers and other associates; scrutinizing their off-station activities; questioning their marital statuses; and even pondering reasons for their masculine or feminine personality traits (Humphrey 1990). Obviously such criteria leave ample room for misinterpretation and mistakes in legal investigations, if not opportunity for outright sabotage of military careers. Just being homosexual in the military is grounds for an "incompatibility" discharge; while committing sodomy, defined as a criminal act in the Uniform Code of Military Justice (sec. 125), may be punishable by prison terms ranging from five to 20 years.

The hostility of the military toward homosexuals is magnified by the lack of discretion allowed commanding officers in dealing with homosexual service members. Commanding officers must instigate investigations into the alleged homosexuality of suspect service members, or themselves be considered derelict of duty (UCMJ art. 92). 
This policy prevents commanding officers from allowing exemptions from discharge for any homosexual, even the most valuable and dependable of service members.

The contemporary U.S. military has made considerable efforts to protect racial minorities and women from discrimination in the services, and to provide them with as many career opportunities as possible. The official status of homosexuals in the services, however, remains only slightly different today than it was at the very inception of United States military.

United States military history is replete with information about racial minority and women service members, because even when these groups were largely excluded from the "core" of the military services, they were, nonetheless, allowed to serve in lower-status, segregated units. Homosexuals in the U.S. military have never been segregated into their own units, which might have given them an opportunity to prove their abilities in military service, or leave a historical mark of some kind. Upon discovery, they were usually (and quickly) discharged from service. Their history comes from interviews and anecdotes provided by past and present service members, quietly told in order to avoid repercussions by military authorities. Therefore the "history" of homosexuals in the U.S. military is most easily illustrated through an 
examination of the service policies concerning them, combined with court cases and literary anecdotes. The following section attempts an examination of the status of homosexual service members in a historical context.

\section{Historical Perspective}

Like racial minorities and women, homosexuals have always been involved in the defense of the United States. The first "known" homosexual service member, a general, made significant contributions to the revolutionary efforts of George Washington's Continental Army.

In 1777, Washington was struggling to unify what were essentially thirteen separate armies provided by the thirteen colonies, all fighting under the same flag. Washington's problems were compounded by his own lack of military training and experience. The new continental Army desperately needed training. Benjamin Franklin attempted to recruit a person he believed could instill the training and military discipline necessary to win the Revolutionary War-- Baron Frederich Wilhelm Ludolf Gerhard Augustin von Steuben, a European military genius. Steuben had been an aide to King Frederick II of Prussia, Europe's most notorious gay ruler at the time (shilts 1993, p. 7), and a brilliant military strategist. Steuben's experience and discipline, Franklin believed, could give the continental Army a fighting chance against 
the well-trained and experienced British forces. steuben abruptly left Europe for America, however, only after being accused of "...having taken familiarities with young boys which the law forbids and punishes severely...." (Shilts 1993, p. 8).

steuben arrived at Valley Forge on February 23, 1778. Washington asked him to review the troops and offer suggestions for improvement. Upon inspection, steuben found that some of the regiments drilled in the French style, others in the English or Prussian styles. Steuben wrote a drill book and formed a model brigade, the members of which became drill masters who trained other drill masters, eventually unifying the Continental Army. In 1783, George Washington's last official act as Commander in Chief of the continental Army was to write a letter thanking steuben (Shilts 1993, p. 11).

General steuben's acceptance in the military was not an indication that homosexuality was acceptable, but rather evidence of desperation on the part of the military. Two weeks after steuben's arrival at Valley Forge, a general court-martial carried out a punishment approved by General Washington, dismissing from service Lieutenant Gotthold Frederick Enslin. Enslin had been "caught" in his private quarters with an enlisted man, and subsequently became the first service member discharged 
from the U.S. military for homosexuality (Shilts 1993, p. 11).

Military policy on homosexuals and homosexual acts may be divided into two categories: statutes used to prosecute service members, and service regulations which exclude or discharge members from the services.

The criminal "offense" of homosexuality first became codified in U.S. military law during the First world war. The Articles of War of 1916, which became effective March 1, 1917, listed among its "miscellaneous" crimes and offenses assault with the intent to commit sodomy (article 93). This first proscription included only anal sodomy, and only if the act was forcible (MCM 1917, para 443).

Following the war, Congress enacted new Articles of War, which were revised so that both anal and oral sodomy became a felonies, whether or not the acts were consensual (MCM 1921, para 443). However the crime of forcible sodomy still applied only to anal intercourse.

The law did not change again until 1951, when the Uniform Code of Military Justice became the military's new body of law. The new law included proscriptions against all types of sodomy, forcible or consensual, whether committed with opposite- or same-sex partners, or with animals (UCMJ art 125). Besides defining more sex acts as crimes, the law also increased the allowable maximum 
punishment. The current maximum punishment for forcible sodomy is dishonorable discharge, forfeiture of all pay and allowances, and imprisonment for 20 years (Davis 1991, p. 74). Even though sodomy has been a court-martial offense since 1920, consensual sodomy among service members has usually led only to administrative separation (Davis 1991, p. 74).

Current regulations regarding homosexuality differ from service to service, but are substantially the same because they are based on the same Department of Defense directives. Following world War II, both the Army and the Navy moved to bar from enlistment all people with "homosexual histories" (Davis 1991, p. 74).

Until 1945, the Army gave dishonorable discharges to enlisted members suspected of homosexual conduct because of their alleged "inaptness or undesirable habits or traits of character" (AR 615-360). In 1945, War Department policy changed to allow for the discharge of some homosexuals, and the retention of "reclaimable" homosexuals. The latter would return to duty after a period of psychiatric hospitalization. By March of 1946, homosexual service members who had not engaged in homosexual conduct could be discharged honorably (Davis 1991, p. 75).

In 1948, the military moved toward a less-tolerant 
policy when the provision for honorable discharge was dropped. Homosexuals were classified as "unfit," along with criminals, pathological liars, drug addicts, and sexual perverts (AR 615-368).

In 1955, Army Regulations divided homosexuals into three categories: Class I homosexuals were those who committed homosexual acts involving assault; Class II homosexuals were those who committed, or attempted to commit consensual homosexual acts; and class III homosexuals were those who exhibited or professed homosexual tendencies, even in the absence of homosexual conduct. Honorable discharge was reinstated for class III homosexual service members who could provide evidence of "heroic" military service; other homosexuals faced sanctions ranging from general discharges to prison sentences (AR 635-89).

In the late 1960s and early 1970s, homosexuals could be discharged as "unfit and unsuitable" (AR 635-200). There were, however, some differences between the services concerning the possibility of exemptions from discharge for some homosexual service members.

(S) eparation boards convened pursuant to AR 635-200 generally had the authority to recommend retention of soldiers being processed for elimination, (but) commanders could disapprove a board's recommendation to separate. This provided two loopholes for some homosexuals, even though the Army policy was that homosexuality is incompatible with military 


\begin{abstract}
service. A similar situation developed with
officer separations, because the officer elimination regulation implied that separation was discretionary. Indeed, prior to February 1977, the Army's litigation posture was that there was discretion to retain homosexuals.

Meanwhile...the Navy regulation on

homosexuality, dated July 31, 1972, did not provide any terms of exception to the general policy of separating homosexuals. In litigation in 1974, however, the Navy argued that the regulation did not require mandatory discharge of homosexuals (Davis 1991, p. 77).
\end{abstract}

The ambiguous service regulations were tested through litigation as some homosexual service members attempted to retain their military careers. In a 1975 case, an Air Force Technical Sergeant applied for an exception to the discharge policy, but his request was denied because the Air Force claimed his case lacked the "unusual circumstances" required to warrant the exception. Further frustrating the efforts by homosexual airmen to retain their careers is the fact that the Air Force does not define "unusual circumstances" (Davis 1991, p. 78).

In 1980, a Federal court found that the Army's definition of unsuitability due to homosexual "tendencies, desires, and interests" was an unconstitutional violation of service members' right to privacy. The Army responded by changing the definition of "homosexual" so that it could retain its policy of exclusion (Davis 1991, p. 78). In 1981, AR 635-200 was revised, making it clear that any service member fitting the description of "homosexual" 
must be discharged. One year later, the Department of Defense issued a directive that made the total exclusion policy uniform across the services (DOD 1982).

This policy remained in effect until 1993 when President clinton's "Don't Ask, Don't Tell" compromise with the military service secretaries allowed homosexuals to serve in the military as long as they made no public admission of their homosexuality. The primary affect of the new policy is that the military services are no longer allowed to ask about sexual orientation as a condition of recruitment, or promotion of service members. However, the policy allows the military to pursue the discharges of any service members who admit they are homosexuals, regardless of their conduct.

Some homosexual service members have fought their discharges in Federal Appellate courts, with mixed results: a few have been reinstated while the military fights their appeals, but most have been honorably discharged. Such court cases, and President clinton's campaign promise to lift the ban on homosexual service members, have had the affect of focusing public attention on the military's exclusionary policy toward homosexuals. The following section outlines public perception of the reasons for and against the exclusion, as reflected in statements culled from New York Times articles surrounding 
the date of clinton's policy compromise.

\section{Findings}

Summarized in Table III are the data collected from 50 New York Times articles surrounding July 16, 1993, the date of announcement of the "Don't Ask, Don't Tell" compromise policy which allowed homosexuals to serve in the U.S. military as long as they kept their sexual orientations secret. The New York Times Index was searched backward and forward from this date until 50 appropriate entries were found. This method of searching produced a window from May 28, 1993, to september 3, 1993, 49 days before and 49 days after the JuIy 16, 1993 compromise plan. Four of the articles listed in the New York Times Index made references to homosexuals in the military without discussing the controversy surrounding their service. These four articles contained no useful data. Contents of the remaining 46 articles were analyzed.

\section{Analysis}

Despite the heated opposition toward homosexuals within the military (as illustrated by military history and service policies), the solid majority of statements concerning the issue supported the reformist stance. 
TABLE III

\begin{abstract}
DISTRIBUTION OF 353 STATEMENTS IN FAVOR OF, AND OPPOSITION TO ALLOWING HOMOSEXUALS TO SERVE IN THE U.S. MILITARY

MAY 28, 1993 TO SEPTEMBER 3, 1993
\end{abstract}

\begin{tabular}{|c|c|c|c|}
\hline \multirow[b]{2}{*}{ RATIONALE } & \multicolumn{2}{|c|}{ STANCE } & \multirow[b]{2}{*}{$n^{\text {Total }}(8)$} \\
\hline & $\begin{array}{c}\text { Exclusionist } \\
n \quad(8)\end{array}$ & $\begin{array}{c}\text { Reformist } \\
\mathrm{n} \quad(8)\end{array}$ & \\
\hline Ideological & $14(4.0)$ & $132(37.4)$ & $146 \quad(41.4)$ \\
\hline Interdependence & $2 \quad(0.6)$ & $15 \quad(4.2)$ & $(4.8)$ \\
\hline Self-Categorical & $94 \quad(26.6)$ & $9 \quad(2.5)$ & $(29.1)$ \\
\hline Bureaucratic & $18 \quad(5.1)$ & $69(19.6)$ & $87 \quad(24.7)$ \\
\hline Total & $128(36.3)$ & $225(63.7)$ & $353(100.0)$ \\
\hline
\end{tabular}

Nearly 64 percent of statements suggested that homosexuals should be allowed to serve, while only 36 percent supported the exclusionary policy.

Reformist statements about homosexuals followed the pattern of reformist statements regarding racial minorities and women-- they were largely ideological in character, rather than addressing the practical matters of cohesion among service members. Thirty-seven percent of statements relied on reformist appeals to ideological concepts of fairness and equal rights. Typical statements cited the fundamental rights of homosexuals [H42], principles of fairness and human dignity [H17], equal protection quarantees found in the constitution [H44], and the abhorrence of discrimination...based on sexual status [H9]. One college student quoted in an article summed up reformists" ideological rationale thus: "The military is a 
representative of America, and needs to live up to democratic values even if it isn't a democratic institution per se" [H9].

By contrast, only four percent of the statements supported the exclusionist stance with an ideological rationale. Those mostly argued that such things as "coming out" is not protected speech [H32], that homosexual lifestyles should not be endorsed [H39], that homosexuality is an offense to christian values [H1], and a degradation of morality [H3]. Again, the ideological rhetoric does not address the question of cohesion among service members at the small-unit level.

Statements that were classified as interdependent in character made up just less than five percent of the total number of statements. Reformists argued that service members would follow whatever orders they're given [H50], implying that doing the job and functioning together is more important than getting along. Reformists also assert that homosexual service members have served with distinction [H13], and continue to serve admirably [H18], indicating that heterosexual service members have worked with homosexuals, knowingly or unknowingly, without the predicted disruption of military organization or effectiveness. Another article points out that in time, soldiers respect those who get the job done [H15]. 
Senator Goldwater illustrated the reformist/interdependent position when he derided the exclusion as a senseless move to eliminate "proven military assets" [H11].

statements that supported the exclusionist stance with an interdependent rationale included only references to jeopardized military readiness and combat readiness [H11] [H39], indicating a breakdown of the military organization, but without explicitly describing how such things are affected by the presence of homosexual service members.

The reformist position rarely used self-categorical statements for support. Self-categorical reformist statements constituted only 2.5 percent of the total statements classified. These few suggested that the military had more to fear from macho males than from gays [H9], that negative stereotypes had a greater disrupting effect than the presence of homosexuals [H30], that gaybashing was a problem in the military [H31], and that the prejudices of others should not be a reason for excluding homosexuals [H32]. All of these statements suggest that homosexuals are perceived differently from the majority of service members, but the point is made that the problem does not lie with homosexuals, but with the military culture that is hostile toward them. still another article suggested that shared experiences -- an important 
concept in the self-categorical model of group cohesion -could reshape service members' attitudes: "A heterosexual chief petty officer with 18 years of Navy service, said he had served on submarines with declared homosexuals who worked well with their shipmates," and that people would get used to serving with homosexuals [H5].

Self-categorical statements were utilized much more frequently to support the exclusionist stance. More than 26 percent of the total number of statements were classified as exclusionist and self-categorical in character. These statements suggested that most service members loathed everything to do with homosexuality [H36], that homosexuals were a weak link due to...homosexuality [H20], and that homosexuality is perceived as disgusting, sick and scary [H2]. clearly such sentiments would function to isolate homosexual service members from heterosexual ones. Whether or not such beliefs are grounded in reality, they could certainly affect the cohesion of small units, because hatred of some members by others in the group prevents them from identifying with one another, a key to cohesion in the self-categorization model.

A fairly large number of bureaucratic statements were employed to support the reformist stance. More than 19 percent of the total number of statements fell into this 
classification. They focused almost exclusively on the qualifications of individuals to fill certain jobs, and the ability of the military to enforce codes of conduct. Arguments included such statements as "if a gay person is the most qualified candidate, let her or him in" [H5], homosexuals should serve if they play by the rules [H26], and emphasis should be placed on behavior and conduct [H39] rather than sexual orientation. There were further suggestions that the military would solve its homosexual "problem" if violations of the Uniform Code of Military Justice were investigated in an evenhanded manner without regard to whether the conduct was heterosexual or homosexual [H28], and if the practice of selective enforcement of rules was ended [H26]. The gist of the reformist bureaucratic rationale is that qualification and conduct should be the only criteria for enlisting and advancing service members.

Very few exclusionist statements were classified as bureaucratic. They constituted only five percent of the total number of statements classified. The majority of these statements followed a circular argument, contending that because homosexuality is defined as "incompatible with military service" (DOD 1982), and homosexual acts are considered illegal conduct [H42] in the Uniform code of Military Justice (art. 125), homosexuality was by 
definition against the rules, and homosexuals should therefore be excluded from the services. Further, attempts to change military policies to include homosexual service members would lead to court challenges [H41] and legal quagmires [H33]. One article pointed out that service members have fewer constitutional rights than civilians [H42], apparently in an attempt to justify the exclusion. Another article suggested that the exclusion functioned to protect gays from threats of violence within the services [H15]. Interestingly, no references were made to the qualifications of homosexual service members. The examination of the 353 statements regarding the military's discriminatory policies toward homosexuals (Table III) shows that a larger number of statements, 63.7 percent, supported the reformist stance, despite the military's blatant hostility toward homosexuals. Factors which might help account for this historical and continuing hostility are outlined in the following sections.

\section{The Political Context}

During the 1992 presidential campaign, the political pendulum generally appeared to be taking a liberal swing. People had grown tired of a stagnant economy, which they blamed on 12 years of Republican administration, and the "family values" -- code words for rigid conservativism -- 
which that administration espoused. Democratic candidate Bill clinton, portraying himself as a "Kennedyesque" candidate of a new generation, promised change.

The issue of homosexuals in the military might never have become a debate in the public domain if not for Clinton's presidential campaign promise to lift the ban on their military service. The promise was presumably intended to consolidate the political support of homosexuals, who in 1992 were becoming much more vocal and politically organized, and the support of women. Women and homosexuals both could relate to the institutionalized discrimination of the U.S. military, and both had much to gain from the liberalization of sexual norms. Had clinton been successful in removing all limits on homosexuals' military service, new policies could have compelled service members to refrain from discriminating against them.

Although lifting the ban on gays in the military was only a small part of clinton's national agenda, resistance from the military, including the Joint Chiefs of staff, turned what could have been a simple change of military policy into a lightning rod for public debate. President clinton, in only his first month of office, was now forced to contend with a "crisis" of his own making. Unable to lift the ban outright, the new president was eventually 
forced to settle for a compromise which allowed homosexuals to serve as long as they hid their sexual orientation. The new policy, of course, did not greatly affect the everyday lives of gays in the military because they had already learned to act "straight" in order to protect their military careers.

\section{The Military Context}

Several factors within the military added to the hostility toward clinton's proposal to lift the ban. First is the generally conservative culture of military people, who may have been deeply disappointed that clinton had won the election in the first place. As a student in the 1960s, Clinton had visited the Soviet Union, a sworn enemy of the United States and an immediate military threat; he had protested the war in Vietnam (while living in Great Britain, no less); and he had allegedly used illegal drugs. Such activities would be an affront to the conformity, authoritarianism and nationalism embedded in military culture.

The greatest offense, however, was the perception that clinton's circumvention of military service in Vietnam was an attempt at "draft-dodging." In a culture where male toughness, bravery and sacrifice are highly valued, deferment from military service is viewed as nothing less than a cowardly attempt to shirk 
responsibility.

Adding injury to insult, defense budget increases that characterized the 1980 s would now be replaced by deep defense cuts. Service members were forced to face the fact that their jobs were no longer "safe," that, in fact, competition for promotion would be much more fierce. Even retaining an old billet no longer depended on competence in that job-- the military would now actively purge as many "under-motivated" service members as possible through "attrition." The dreaded acceptance of homosexuals into the military only served to escalate fears of competition among service members, as well as to offend the embedded military culture.

\section{A Feminist Perspective}

The hyper-masculine culture of the U.S. military was discussed in the preceding section about women, but it should be addressed again here. Stereotypes about the effeminate gay male pervade military culture and strike fear in the hearts of service members, especially men. Anyone or anything not masculine enough is despised in this environment. Much of the hostility toward gays in the military is explained by shilts (1993, p. 5-6):

We are a nation in transition when it comes to attitudes toward gender roles and sexuality in general, and homosexuality in particular.

Military service was once considered a rite of male passage. ... In different ways, the 
presence of women and gays in the ranks challenges the traditional concept of manhood in the military, just as the emergence of women and gays in other fields has done so in society at large.

...(T) he presence of gay men -- especially so many who are thoroughly competent for military service -- calls into question everything that manhood is supposed to mean. For both women and men, the story of gays in the military is a story about manhood. For generations, after all, the military has been an institution that has promised to do one thing, if nothing else, and that is to take a boy and make him a man.

It is clear that traditional gender roles play a major part in military attitudes toward both "straight" women and homosexuals of either sex. For women, however, the exclusion of homosexuals from the military has had even more insidious consequences than might at first be suspected. There exists much ambivalence about women's roles in the military because in order to do "men's jobs" proficiently, they must display at least some degree of masculinity, but at the same time they must display femininity to be "real" women. This leaves women in a position of having to prove both their job competence and their heterosexuality. This, in turn, leaves women extremely vulnerable to sexual harassment in the military. Again, Shilts (1993, p. 5) illustrates the point:

There are many men who never wanted women in their Army or their Navy in the first place, and the military regulations regarding homosexuality have been the way to keep them out for the past decade. Until proven otherwise, women in the military are often suspected of being lesbian. Why else, the logic goes, would they want to 
join a man's world? ... If they are successful, they are suspect for not being womanly enough; if they fail, they are harassed for not being man enough to do the job.

The way women can prove themselves to be nonlesbians is to have sex with men. Thus antigay regulations have encouraged sexual harassment of women. Those who will not acquiesce to a colleague's advances are routinely accused of being lesbian and are subject to discharge. Some women have allowed themselves to be raped by male officers, afraid that the alternative would be a charge of lesbianism. Those who do complain of sexual harassment often find themselves accused: Their commands are far more intrigued with investigating homosexuals than with investigating sexual harassment (emphasis in original).

Thus, despite heterosexual male service members' fears of gay men in the military, women are much more affected by the military's homosexual exclusion than are men. After all, homosexual men need only to be competent at "men's jobs" to display their masculinity, and therefore their heterosexuality. Women service members, on the other hand, face the paradox that technical job competence can threaten their military careers. This paradox, combined with the popular belief that a larger percentage of female service members are homosexual results in women being discharged for homosexuality at a much higher rate than are men:

For years there has been great controversy over the fact that women are subjected to witch hunts more often than men. Overall, women comprise about one tenth of total military personnel, yet the percentages for females discharged are three or four times greater than 
those for males.... of the Army's total discharges, 5 percent were enlisted gay men compared to 17 percent enlisted gay women. The Navy had 13 percent of enlisted men discharged for homosexuality and 27 percent of enlisted women. The Marine Corps discharged 4 percent of enlisted men for being gay and 33 percent of enlisted women. ... The Air Force discharged 4.3 percent of enlisted men for homosexuality and 10 percent of enlisted women (Humphrey 1990, p. $\mathrm{x} x \mathrm{~V}$ ) .

The indication is that women's status in the military is inextricably linked to the status of homosexuals, whatever the sexual orientation of women service members. That service members' preoccupation with homosexuality seems at first to be directed toward males may be a simple function of the fact that most service members are male, and, therefore, the presence of homosexual men is the most immediate threat-- both physically (from sexual assaults) and psychically (from sexual ambiguity).

Another observation may reveal that the hostility of "straight" male service members toward homosexuals is related to a perceived threat to gender relations. For example, male homosexuals are perceived by heterosexual male service members as refusing to condemn femininity or subjugate women. This perceived lack of masculinity is viewed as a weakness which reflects upon other males in the services. On the other hand, homosexuality among women is viewed as a rejection of men and men's important role as protectors. Therefore the independence of 
lesbians from men threatens masculinity by making it less crucial, or even important.

Perhaps the greatest of all dangers, perceived only in the subconscious, is the fact that sexual orientation is not a visible trait. Homosexuals in the military can generate sexual identity crises among heterosexual service members, especially young males who are trying to establish their masculine identity, in a way that is not possible for racial minorities and women. This is because a heterosexual white male knows he is not black, just as he knows he is not female. But there is nothing about himself which will let him know that he is not a homosexual.

\section{SUMMARY}

A comparison of the data pertaining to the three outgroups examined shows that a large majority of statements, 60 percent, supported the reformist stance. Despite past and current recalcitrance on the part of the military when confronted with such issues, discussions of exclusionist military policies in the media generally reflect support for reform.

Nearly 40 percent of statements, the largest number in any cell, employed the ideological rationale in support of the reformist stance. This illustrates the importance 
of "American values," and appeals to fairness and justice when dealing with equal opportunity (and the lack thereof) in the military. Ideological statements do not address the problem of human relations at the small-unit level.

TABLE IV

SUMMARY TABLE OF THE DISTRIBUTION OF 653 STATEMENTS FAVORING AND/OR OPPOSING DISCRIMINATORY POLICIES

IN THE U.S. MILITARY

\begin{tabular}{|c|c|c|c|c|}
\hline \multirow[b]{2}{*}{ RATIONALE } & \multicolumn{2}{|c|}{ STANCE } & & \\
\hline & $\begin{array}{c}\text { Exclusionist } \\
n \quad(8)\end{array}$ & $\begin{array}{c}\text { Reformist } \\
n \quad(8)\end{array}$ & \multicolumn{2}{|c|}{ Total } \\
\hline Ideological & $34 \quad(5.2)$ & $259(39.7)$ & 293 & $(44.9)$ \\
\hline Interdependence & $10 \quad(1.5)$ & $15 \quad(2.3)$ & 25 & $(3.8)$ \\
\hline Self-Categorical & $144(22.1)$ & $19 \quad(2.9)$ & 163 & $(25.0)$ \\
\hline Bureaucratic & $71(10.9)$ & $101(15.4)$ & 172 & $(26.3)$ \\
\hline Total & $259(39.7)$ & $394(60.3)$ & 653 & $(100.0)$ \\
\hline
\end{tabular}

The use of these statements does not suggest that small group cohesion will be unaffected by the inclusion of outgroups, just that fairness and equal treatment of people are more important.

The reformist stance relied on the bureaucratic rationale as its next strongest source of support. Again, this model ignores the reality of interpersonal relations at the small-unit level. Instead it focuses on merit and qualification of individuals, who then become akin to interchangeable parts with other people who hold the same qualifications.

The reformist stance made very little use of the 
interdependent or self-categorical rationales. The two combined were only slightly more than five percent of the total number of statements. The reformist stance, then, most frequently relied for support on ideas that ignore the problem of small-unit cohesion in the military. Instead, the focus is on fairness and meritocratic treatment of people.

As expected, the exclusionist stance claimed threats to small-unit cohesion, relying in particular upon the self-categorical model for support. Twenty-two percent of the total number of statements, the largest number in support of the exclusionist stance, employed the selfcategorical statements. Exclusionists apparently recognized the fact that people's ability to bond to others in their primary group affects their ability to perform their function in the organization. Some people's inability to identify with other people because of their categorical differences causes divisions within the group and compromises cohesion and group function.

The next most often used rationale in support of the exclusionist stance came from the bureaucratic model. One possible explanation for this is that there is, in fact, evidence that racial minorities and women achieve lower scores than the white male majority on standardized tests given by the military, which would justify exclusionary 
policies. For example, women are generally smaller than men, possess less muscle mass -- especially in the upper body -- and are unable, on the average, to run as fast as men. This fact is easily quantifiable on standardized physical fitness tests. Physical strength and speed are prerequisites for some jobs in the military, and given that women's strength and speed are generally less than men's, this bureaucratic requirement has been used to justify barring all women from competing for particular jobs. A similar circumstance affects black military recruits when their Armed Services Vocational Aptitude Battery (ASVAB) scores are compared to those of whites. Whites achieve significantly higher average ASVAB scores (Binkin and Eitelberg, 1982 p. 97), providing empirical "evidence" that whites are more qualified for particular jobs and promotions than blacks. This "evidence" has been used in the past to justify discriminatory policies affecting racial minorities.

The exclusionist stance employed very few ideological or interdependent statements as a basis of support. statements fitting into these two rationales constituted less than seven percent of the total number of statements. The majority of these, 5.2 percent, were ideological arguments, usually citing military tradition as a reason not to change the status quo. 
The exclusionist position, then, relied mostly upon self-categorical justifications for excluding outgroups from military service. It is suggested that outgroups should be excluded because the majority of service members simply do not like them. This rationale confirms one of the original assumptions of this thesis-- that arguments supporting the exclusion of outgroups would be couched in the language of small group theory, in this case, as a threat to unit cohesion based on the self-categorization of service members. However, the rationale completely ignores Merton's (1976) point that prejudicial feelings toward others do not necessarily lead to discrimination. Exclusionary policies were further supported by the bureaucratic rationale, with suggestions that whole categories of people were generally not qualified to hold particular jobs in the military. This rationale instills in the exclusionist stance an appearance of meritocracy, without addressing the possibility that the military's standardized exams might be designed to favor particular categories of people.

A breakdown of the distribution of statements among the three groups examined (Table $\mathrm{V}$ below) shows that there are similar patterns in rationale used for each case. 
TABLE V

SUMMARY TABLE OF THE DISTRIBUTION OF 653 STATEMENTS FAVORING AND OPPOSING DISCRIMINATORY POLICIES IN THE UNITED STATES MILITARY

STANCE BY OUTGROUP BY RATIONALE

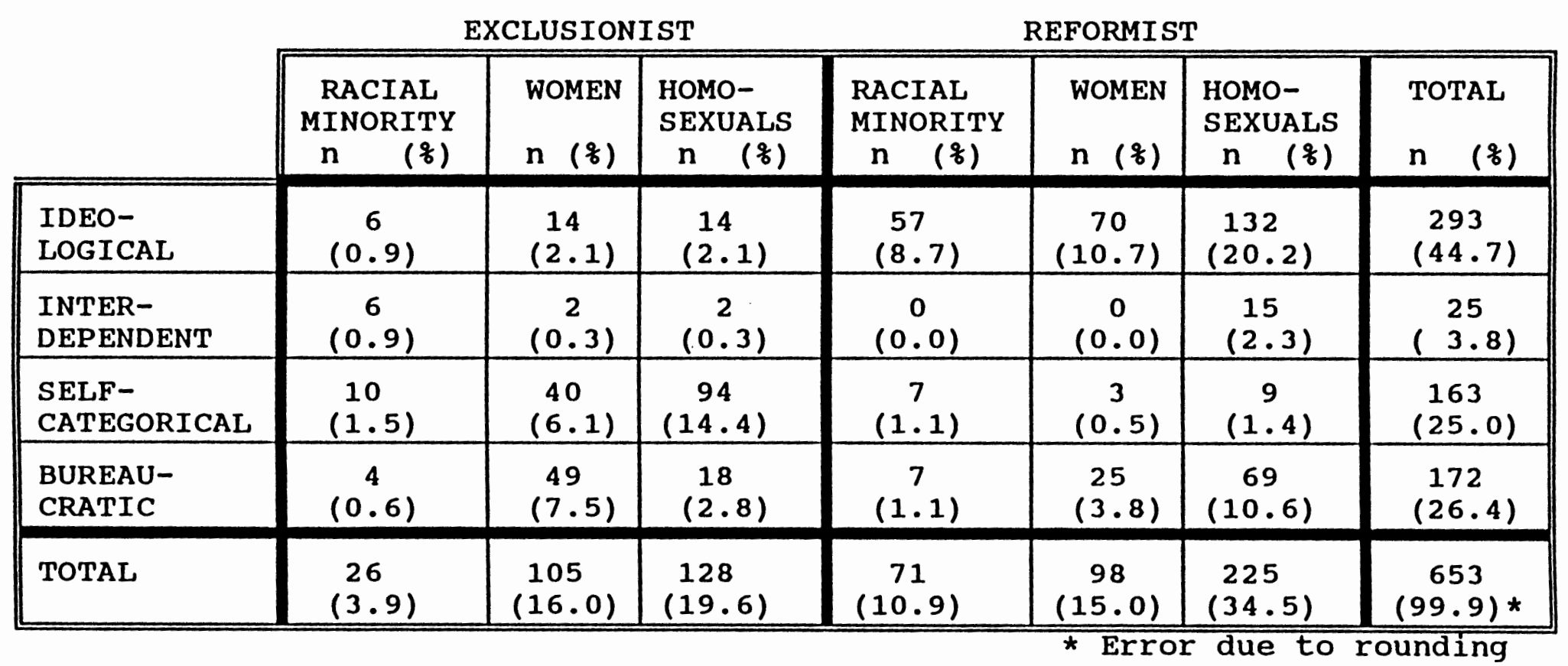


The exclusionist stance most frequently employed self-categorical statements, except in the case of women, in which bureaucratic statements were used slightly more often than self-categorical statements. Least used was the interdependent rationale, except in the case of racial minorities in which bureaucratic statements were least used.

For all three outgroups, the reformist stance relied most heavily upon ideological appeals to equality and fairness for support, and relied next most often upon the bureaucratic model, except in the case of racial minorities for which bureaucratic and self-categorical statements were used in equal numbers. Least used in support of the reformist stance were interdependent statements, except in the case of homosexuals, for which self-categorical statements were used least.

An important aspect of the distribution of statements is the unequal numbers of statements concerning each of the three outgroups. Frequencies of statements might be used as an indication of the level of controversy surrounding each group.

For example, the issue of racial desegregation of the military generated only 97 statements drawn from only 31 New York Times articles over a period of two years, the 
time limit set in the research methodology (for further discussion, see Chapter III -- Methodology). However, the issue of women in combat or subject to the draft generated 203 statements from 50 New York Times articles (the maximum number allowed by the research methodology) in a space of only 700 days. This suggests that the issues of women in combat or subject to the draft were more controversial than the issue of racial desegregation in the military.

The proposal to lift the ban on military service by homosexuals produced 353 statements drawn from 50 New York Times articles published in a space of only 98 days. These data were gathered from a much smaller window of time than was required for either racial minorities or women. Further, the articles concerning homosexuals produced more statements than the number of statements concerning racial minorities and women combined. This suggests that the issue of homosexuals in the military is a far more controversial issue than the military service of racial minorities or women.

Another important aspect concerning the distribution of statements is that it shows that precedence, in this case the change of policy to remove institutionalized discrimination against one outgroup, does not mean that other outgroups will be more readily accepted in the 
future. Laymen's logic may dictate that racial desegregation of the military should have made the acceptance of women less difficult, and that the acceptance of women, in turn, should have made the acceptance of homosexuals less difficult. The data show that just the opposite is true. For each successive outgroup, greater numbers of statements supporting and opposing discriminatory policies in the military were found in shorter time periods. 


\section{CHAPTER V}

\section{CONCLUSION}

The United States military, the most powerful fighting force in the world, is viewed by some Americans as vulnerable to destruction from within. The destruction would not come from espionage or violence, they fear, but rather from social change.

Members of the military organization derive much status in society from the "military mystique," the idea that service members are an elite group. Service members are thought of as brave, tough, well-disciplined, heroic, patriotic, physically fit and willing to die for American ideals. Such characteristics are highly valued, and happily attributed to the American ideal "boy next door." However, it appears that great offense is taken by many people, both inside and outside the military services, if the "boy next door" is not the white male heterosexual they envisioned. Perhaps it is too difficult to attribute the high-status military mystique to less valued groups of people-- racial minorities, women and homosexuals.

Categorical distinctions between people in the military remain important despite the military's best 
effort to strip away people's individualism, and to make such distinctions irrelevant. Recognizing this fact has given credibility to those who favor excluding whole categories of people from service in an attempt to avoid small-unit disruptions based upon such distinctions. Exclusionists recognize that the military's rigid bureaucratic roles and standards of behavior-- and even its body of criminal law designed to enforce such standards, may not save it from the social reality that some categories of people are more favored than others, and that service members may treat each other accordingly. Reformists, on the other hand, largely ignore the issue of small-unit cohesion. They point out that American ideals of freedom and equal opportunity are so important that they cannot be disregarded in any social context -- not even in the military -- and that protecting these ideals could be accomplished through reform of military policy and strict enforcement of rules of conduct. Modified rules of conduct, combined with strict enforcement, could then allow the military to demand nondiscriminatory behavior among service members. Failure to follow such rules could result in disciplinary action ranging from verbal reprimand to execution.

Even though this ideological argument avoids the issue of small-group interaction, the reformist stance has 
generated wider support than exists for the exclusionist stance, as illustrated in the news media. The data suggest that ideology is a very powerful motivating force for change.

The fact that ideological arguments have shaped the military despite neglecting the issue of small-group interaction is evidenced in the fact that the military has changed. Racial minorities are no longer segregated from whites; rather they are included in all services, jobs and ranks without race-based limitations. Women are now part of the regular services and are allowed to achieve any rank without limitation. Although they are still exempt from registration for the draft and barred from competition for many combat-related jobs, military women find more and more opportunities are open to them. Women are allowed to serve aboard combat ships and aircraft, compete in non-segregated service academies, and they receive combat training along with men in non-segregated basic training units. Homosexuals have been acknowledged as assets to the military, as long as they do not draw attention to their sexual orientation or engage in unlawful behavior. Simple acknowledgement in this case is viewed as another first step toward reform.

Even if racial minorities, women and homosexuals are not the ideal "boys next door," it has been proved through 
experience that their presence is more beneficial than detrimental to the overall function of the U.S. military. Further, bestowing some of the "military mystique" upon these social outgroups might help to elevate their status in the larger society. 


\section{REFERENCES}

Army Regulation 600-443. Personnel, Separation of Homosexuals (1950).

Army Regulation 615-360, Enlisted Men, Discharge; Release From Active Duty, para. 51-56 (26 Nov. 1942); para. 51-56 (04 Apr. 1935); para. 49-54 (14 Sep. 1927); para. 49-54 (06 Dec. 1922).

Army Regulation 615-368, Enlisted Men, Discharge, Undesirable Habits or Traits of Character, para. 2 (27 Oct. 1948).

Army Regulation 635-89, Personnel Separations, Homosexuals, para. 3. (1955).

Army Regulation 635-200, Personnel Separations, Enlisted Personnel, paras. 13, 14. (15 Jul. 1966).

Becker, Howard S. 1960. "Notes on the Concept of Commitment." American Journal of Sociology. July. Volume LXVI, Number 1.

Benveniste, Guy. 1977. Bureaucracy.

San Francisco: Boyd \& Fraser Publishing Co.

Berg, Bruce I. 1989. Qualitative Research Methods for the Social Sciences. Boston: Allyn and Bacon.

Binkin, Martin, and Mark J. Eitelberg. 1982. Blacks and the Military. Washington, D.C.: The Brookings Institution.

Bishop, Joseph W. 1974. Justice Under Fire.

New York: Charterhouse.

Blau, Peter M. 1964. Exchange and Power in Social Life. New Brunswick: Transaction Books

- 1974. On the Nature of Organizations. New York: John Wiley \& Sons. 
Boles, Janet K. 1979. The Politics of the Equal Rights Amendment: Conflict and the Decision Process. New York: Longman.

Bourne, Peter G. 1970. Men, stress, and Vietnam. Boston: Little, Brown, and Company.

Bryant, Clifton D. 1979. Khaki-Collar Crime. New York: Macmillan Publishing Co., Inc.

Coser, Lewis A. and Bernard Rosenberg, ed. 1982. Sociological Theory, 5th ed. New York: Macmillan Publishing Co.

Crozier, Michael. 1964. The Bureaucratic Phenomenon. Chicago: University of Chicago Press.

Davis, Jeffrey S. 1991. Military Policy Toward Homosexuals: Scientific, Historical, and Legal Perspectives. Military Law Review, Vol. 131, pp. 55108 .

Department of the Army ROTC Manual (ROTCM 145-85) . 1975 . Fundamentals of Military Law. Washington D.C.: U.S. Govt. Printing office.

Department of Defense. 1982. Hispanics in America's Defense. Washington, D.C.: Pentagon: U.S. Government Printing office.

Department of Defense. 1985. Black Americans in Defense of Our Nation. Washington, D.C.: U.S. Government Printing office.

Department of Defense Directive 1332.14, Enlisted Administrative Separations (Jan. 28, 1982).

Department of Defense Directive 1332.30, Separation of Regular Comissioned officers for Cause (Feb. 12, 1986).

Dornbusch, Sanford M. 1955. The Military Academy as an Assimilating Institution. University of North Carolina Press.

Executive order (of the President) 9981. July 26, 1948.

Frazier, E. Franklin. 1957. The Negro in the United States. (rev. ed.) New York: MacMillan Co. 
Goffman, Erving. 1961. Asylums: Essays on the Social Situation of Mental Patients and other Inmates. New York: Doubleday \& Co.

Holm, Jeanne. 1982. Women in the Military. Novato, CA: Presidio Press.

Homans, George C. 1958. "Social Behavior as Exchange." Pp. 597-600 in The American Journal of Sociology, Vol.63, No. 6 .

Humphrey, Mary Ann. 1990. My Country, My Right to Serve. New York: Harper Collins Publishers.

Janowitz, Morris. 1959. Sociology and the Military Establishment. New York: Russell Sage Foundation.

Johnson, Allan G. 1992. Human Arrangements: An Introduction to Sociology, 3rd ed. New York: Harcourt Brace Jovanovich.

MacGregor, Morris J. 1981. Integration of the Armed Forces 1940-1965. [Defense study Series] Washington, D.C.: Center of Military History -- United States Army.

Mansbridge, Jane. "Why We Lost the ERA." In Sex, Gender, and the Politics of the ERA, ed. Mathews and DeHart, pp 26-27. New York: Oxford University Press, 1990.

Manual for Courts Martial, Appendix 2: Uniform Code of Military Justice. 10 U.S.C. (1982).

Manual for Courts Martial, United States, 1917.

Manual for Courts Martial, United States, 1921.

Mathews, Doanld G., and Jane Sherron DeHart. 1990. Sex, Gender, and the Politics of the ERA. New York: oxford University Press.

McGrath, Joseph. 1984. Groups: Interaction and

Performance. Englewood Cliffs: Prentice-Hall.

Merton, Robert K. 1976. Sociological Ambivalence and other Essays. New York: The Free Press.

Mills, C. Wright. 1959. The Sociological Imagination. New York: Oxford University Press. 
Moore, M. 1989. Women in the Military. The oregonian. Oct. 29 , sec. $A-2$.

Nalty, Bernard C. 1986. Strength for the Fight: A History of Black Americans in the Military. New York: The Free Press.

Palola, Ernest G. and Joseph F. Jones. 1965. "Contrasts in Organizational Features and Role Strains Between Psychiatric and Pediatric Wards." Pp. 141-147 in Journal of Health and Human Behavior, Vol. 6. Fall.

Powell, Colin. 1992. Quoted by David Wood in "Military Draws Line at Gays in Combat" in The oregonian. Sec. A, P. 2. December 14 .

Public Law 625: Women's Armed Services Act. June 1948.

RAND: National Defense Research Institute. 1993. Sexual orientation and U.S. Military Personnel Policy: options and Asessment. Santa Monica, CA: RAND.

Reardon, Betty A. 1985. Sexism and the War system. New York: Columbia University.

Rivkin, Robert S. 1973. The Rights of Servicemen. U.S.A.: The American Civil Liberties Union.

Rogan, Helen. 1981. Mixed Company: Women in the Modern Army. New York: G. P. Putnam's Sons.

Rustad, Michael. 1982. Women in Khaki: The American Enlisted Woman. New York: Praeger Publishers.

Schug, Willis, ed. 1972. United States Law and the Armed Forces. New York: Praeger Publishers.

Scott, W. Richard. 1992 . organizations: Rational, Natural, and Open Systems. Englewood Cliffs, NJ: Prentice $\mathrm{Hall}$.

Shaw, M.E. 1976. "Group Dynamics: The Psychology of Small Group Behavior" in Rediscovering the Social Group. by John C. Turner. 1987. New York: Oxford University press.

Sherif, Muzafer, and Carolyn W. Sherif. 1964. Reference Groups: Exploration into Conformity and Deviation of Adolescents. New York: Harper and Row. 
Sherrill, Robert. 1970. Military Justice is to Justice as Military Music is to Music. New York: Harper \& Row.

Shilts, Randy. 1993. Conduct Unbecoming. New York: St. Martin's Press.

Stiehm, Judith H. 1989. Arms and the Enlisted Woman. Philadelphia: Temple University Press.

- 1981. Bring Me Men \& Women: Mandated Change at the U.S. Air Force Academy. Berkeley: University of California Press.

Turner, John C. 1987. Rediscovering the Social Group: A Self-Categorization Theory. New York: Basil Blackwell Inc.

Tuten, Jeff M. 1982. "The Argument Against Female Combatants" in Female Soldiers-- Combatants or Noncombatants? ed. Nancy Goldman. London: Greenwood Press.

United States codes, Title 10, section 6015 .

United States Codes, Title 10, section 8549 .

Weber, Max. 1946. Essays in Sociology. Edited by H. H. Gerth and $C$. Wright Mills. New York: Oxford University Press.

Wells-Petry, Melissa. 1993. Exclusion: Homosexuals and the Right to serve. Washington, D.C.: Regnery Gateway.

West, Luther C. 1977. They Call It Justice. New York: The Viking Press.

White, Bruce. 1990. "The Army and the Indian" Pp. 69-88 in Ethnic Armies. N. F. Dreisziger, ed. Waterloo, ontario, Canada: Wilfrid Laurier University Press.

(Report of) Working Group on Human Behavior Under Conditions of Military Service. 1951. Office of the Secretary of Defense.

Young, Warren L. 1982. Minorities and the Military: A Cross-National study in the World Perspective. Westport, Conn.: Greenwood Press. 
Zeitlin, Irving M. 1990. Ideology and the Development of Sociological Theory, 4 th ed. New Jersey: PrenticeHall.

Zurcher, Louis A. 1967. "Navy Boot Camp: Role Assimilation in a Total Institution." in Sociological Inquiry, vol. 37 , No. 1. 


\section{APPENDIX A}

BIBLIOGRAPHY: THE NEW YORK TIMES

\section{Racial Minorities}

R1. "Recommendations Made in the Report on Civil Rights and Their Preamble." Oct. 30, 1947. P. 14:8.

R2. "Says 'Brass' Balked on Social Sciences." Jan 30, 1948. P. $4: 8$.

R3. "The Text of President Truman's Message on Civil Rights." Feb 3, 1948. P. 22. (UP).

R4. "Wallace Rejects Bid to Aid Truman." Feb 16, 1948. P. 5:3.

R5. "Negro Defense View Told." Mar 23, 1948. P. 28:4. (AP).

R6. "Negro Votes Urged To Aid Democracy." Mar 28, 1948. P. $30: 3$.

R7. "Air Force Issue Ruled Out." Apr 16, 1948. P. 4. (AP).

R8. "Negro Leaders Quit Army Advisory Role." Apr 27, 1948. P. 17. (AP).

R9. "Republican Party Platform." Jun 22, 1948. P. 2:6.

R10. "Negro Convention Acclaims Truman." Jun 27, 1948. P. 56:1. George streator, NYT staff.

R11. "Truman orders End of Bias In Forces And Federal Jobs; Addresses Congress Today." Jul 27, 1948. P. 1. Anthony Leviero, NYT staff.

R12. "Senate Bloc Plans Rigid 'Rights' Fight." July 27, 1948. P. 4. William S. White, NYT staff.

R13. "Texts of Rights Orders." Jul 27, 1948. P. 4:2. (UP) . 
R14. "Liberals Seen Set To Back Truman." Jul 29, 1948. P. 12 .

R15. "Wallace Assails Special Session." Jul 30, 1948. P. 2 .

R16. "Army Segregation To Go, Says Truman." Jul 30, 1948. P. $2: 8$.

R17. "Dissolution Splits Foes of Draft Bias." Aug 19, 1948. P. 19:3.

R18. "Negroes Propose a 7-Point Plan To stop Segregation in Services." Sep 8, 1948. P. 15:2. Walter H. Waggoner, NYT staff.

R19. "Board On Bias Is Named." Sep 19, 1948. P.61. (UP).

R20. "Christians in VA Hospitals Aid at Jewish Services." Oct 4,1948 . P. $26: 8$.

R21. "Churchwomen Ask Segregation Curb." Nov. 19, 1948. P. 36:1. George Dugan, NYT staff.

R22. "Air Force Proposes a New Policy Pointing to an End of Segregation." Jan 16, 1949. P. 1:2.

R23. "Johnson Orders Racial Equality." Apr 21, 1949. P. 14:4.

R24. "Truman Defended By Negro students." Apr 24, 1949. P. 62:3. George streator, NYT staff.

R25. "Johnson Approves Air Force Plan To Distribute Negroes Among Units." May 12, 1949. P. 1:2.

R26. "Truman Bias Plan Held Ineffectual." Jun 5, 1949. P. 33:1.

R27. "End To Segregation In Services Is Urged." Jun 6, 1949. P. 12:4.

R28. "Johnson Approves Navy Racial Plan." Jun 8, 1949. P. 16:3.

R29. "Medical Plan Defended." Jun 13, 1949. P. 26:5.

R30. "Truman Restates Civil Rights stand." Jul 13, 1949. P. 30:2. George Streator, NYT staff. 
R31. "Army Defies Chief On Racial Policies." Jul 17, 1949. P. 1:7. Walter H. Waggoner, NYT staff.

\section{Women}

w1. "Women's Sea Duty Curb Rejected." July 28, 1978. P. II $2: 1$. Karen DeWitt, NYT staff.

W2. "Navy Chief studying Question of Women on Ships." Aug 10, 1978. P. 86. (AP).

W3. "The Case Against Women In Combat." Jan 28, 1979. P. VI 29. George Gilder. (NYT Magazine).

W4. "Greetings, Young Women." Feb 3, 1979. P. 19:2. Russell Baker.

W5. "Women in Combat." Feb 18, 1979. P. VI 78:1. Danielle R. Bernstein. (letter).

W6. "Sex and the Draft Board." June 2, 1979. P. 22:6. Arthur Murray. (letter).

W7. "Female Sailors Go overseas First Time on U.S. Warship." Sept 12, 1979. P. 14:6. (AP).

W8. "House Bars Registration for Draft; Manpower Study Is Sought Instead." Sep 13, 1979. P. 1:3. Marjorie Hunter, NYT staff.

W9. "Westmoreland Opposes Women in Combat Role." Nov 15, 1979. P. II 17:1. (UPI).

W10. "Army Combat Role For Women Opposed." Nov 18, 1979. P. $28: 1$. (AP).

W11. "When a Woman Is Trained for Combat." Nov 23, 1979. P. 26:1. Jeanne M. Malaty-Uhr. (letter to editor).

W12. "For a Trail-Blazing Navy Flier, Happy Landings on an Aircraft Carrier." Dec 1, 1979. P. 48:2. Richard Halloran, NYT staff.

W13. "No Immediate Need For Call-Up Is Seen." Jan 24, 1980. P. 1:5. Richard Halloran, NYT staff.

W14. "Draft Registration Due Soon, But Uncertainty Remains." Jan 25, 1980. P. 10:5. Richard Halloran, NYT staff. 
W15. "West Point Women Draw Duty in Combat Branches." Jan 25, 1980. P. 1:2. James Feron, NYT staff.

W16. "Prospect of the Draft Gets a Mixed Reaction From Feminists." Jan 25, 1980. P. A 16. Carey Winfrey.

W17. "Wife Hints Carter Backs Female Draft." Jan 26, 1980. P. 9:1. Marjorie Hunter, NYT staff.

W18. "Registering of Women For Draft Is Supported BY Defense Secretary." Jan 29, 1980. P. 16:4.

W19. "Women Assail Draft Registration." Feb 1, 1980. Karen DeWitt, NYT staff.

W20. "Kennedy Lays 'War Hysteria'to Carter." Feb 2, 1980. p. 7:1. Drummond Ayres Jr., NYT staff.

W21. "Poll Reports U.S. Divided on Drafting of Women." Feb 2, 1980. P. 7:2. (AP).

W22. "Republicans Oppose Female Draft." Feb 3, 1980. P. 20:4. Warren Weaver Jr., NYT staff.

W23. "For Women Only." Feb 4, 1980. P. 18:5. Thaddeus A. Budner. (letter).

W24. "Carter Reported Limiting Registry For Draft to Those 18-20 Years Old." Feb 5, 1980. P. 16:1. (AP)

W25. "Most Leaders of Military Oppose Draft of Women." Feb 6, 1980. P. II 4:5. (AP).

W26. "Carter Expected to Urge Registration of Women." Feb 8,1980 . P. 14:1.

W27. "Permission to Die." Feb 8, 1980. P. 30:6. Donna soucy. (letter).

W28. "Carter Draft Plan Urges Reggistration of Men And women." Feb 9, 1980. P. 1:6. Richard Halloran, NYT staff.

W29. "Carter statement on Draft Registration." Feb 9, 1980. P. 8:1.

W30. "150,000 Women Are in Armed Forces." Feb 9, 1980. P. 8:4. Marjorie Hunter, NYT staff. 
W31. "Plan Is Given Cautious Approval by Women's Groups." Feb 9, 1980. P. 9:3. (AP).

W32. "High School students Register Feelings on the Draft." Feb 9, 1980. P. 11:1. Georgia Dullea.

W33. "About Long Island." Feb 10, 1980. P. XXI 2:1. George Vecsey.

W34. "Byrd Says Registration of Women Is 'Divisive'." Feb 11, 1980. P. IV 11:1. (UPI)

W35. "When Religion Forbids Women to Be soldiers." Feb 13, 1980. P. 26:3. (Rabbi) Bernard Rosensweig. (letter).

W36. "Register For What?." Feb 13, 1980. P. 27:5. James Reston.

W37. "Veterans Leader Calls Proposed Registration of Women 'Cop-out'." Feb 14, 1980. P. 13:6. (UPI)

W38. "Oklahoma Opposes Women in Draft." Feb 14, 1980. P. $13: 6$. (AP)

W39. "This Man's Army." Feb 17, 1980. P. IV 19:2. Frances FitzGerald.

W40. "Campus Women React to a Draft." Feb 17, 1980. P. XXII 2:5. J. B. O'Mahoney.

W41. "Registration of Women Meets Obstacle in Congress." Feb 20, 1980. P. 16:1. Richard Halloran, NYT staff.

W42. (Untitled) Feb 20, 1980. P. 24:4. George Zeidenstein. (letter to editor).

W43. (Untitled) Feb 20, 1980. P. 24:5. John Clark. (letter to editor).

W44. "Women Testify Against Plan on Registration for Draft." Feb 21, 1980. P. 16:1. Richard Halloran, NYT staff.

W45. "Labor Leaders Back Registration." Feb 26, 1980. P. $12: 2$. (AP)

W46. "Group in House Expresses Doubt on Draft Signup." Feb 27,1980 . P. 1:2. Richard Halloran, NYT staff. 
W47. "Panel Rejects Funds For Draft Registry." Feb 28, 1980. P. 1:3. Martin Tolchin, NYT staff.

W48. "Personal Beliefs vs. Military service." Feb 28 , 1980. P. 22:5. Robert I. Edenbaum. (letter).

W49. "And Now, the Communication Gap." Mar 5, 1980. P. 26:2. (editorial).

W50. "Plan to Register Females in Draft Fails House-Test." Mar 7, 1980. P. 16:1. Richard Halloran, NYT staff.

Homosexuals

H1. "President Backs A Gay Compromise." May 28, 1993. P. 1:3. Richard L. Berke, NYT staff.

H2. "Killer Gets Life as Navy Says He Hunted Down Gay Sailor." May 28, 1993. P. A 1:2. James Sterngold, NYT staff.

H3. "Excerpts From Clinton's Question-and-Answer Session in the Rose Garden." May 28, 1993. P. A 14:1.

H4. "Joint Chiefs to Get 2 Options on Homosexuals." May 29, 1993. P. I 8:4. Eric Schmitt, NYT staff.

H5. "In the Military, Bolder Talk of Acceptance." May 30, 1993. P. IV 4:1. Eric Schmitt, NYT staff.

H6. "Clinton and Powell Find They Need Each Other." June 4, 1993. P. A 1:5. Eric Schmitt and Yhomas L. Friedman, NYT staff.

H7. "Ballons of Protest For Powell At Harvard." June 9, 1993. P. B 7:6.

H8. "Discharge of Lesbian Urged by Navy Panel." June 11, 1993. P. A 14:1.

H9. "Powell Receives a Rousing Greeting at Harvard." June 11, 1993. P 14:3.

H10. "Goldwater Backs Gay Troops." June 11, 1994. P. A $18: 1$. (AP).

H11. "The Powell Factor." June 14, 1993. P. A 15:1. Anthony Lewis. 
H12. "Military's Zeal Decried in Sodomy Case." June 21 1993. P. A 15:1. Eric Schmitt, NYT staff.

H13. "A Compromise on Military's Gay Ban Is Discussed." June 23, 1993. P. A 20:1.

H14. "The Gap Narrows in Talks on Gay Ban, but Can It Be Bridged?." June 25, 1993. P. A 20:3. Thomas L. Friedman.

H15. "Another Kind of Closet." June 27,1993 . P. IV 15:1. Anna Quindlen.

H16. "White House and Chiefs snagged on Retaining Gay-Ban Language." July 2, 1993. P. A 1:1. Eric Schmitt, NYT staff.

H17. "Bigotry Is What's Incompatible." July 6, 1993. P. A 16:1. (editorial).

H18. "Clinton to Be Given Options for Changing Military's Gay Ban." July 8, 1993. P. A 16:1. Eric Schmitt, NYT staff.

H19. "Protesters Demonstrate Against N.A.A.C.P.'s Support of Homosexuals." July 11, 1993. P. I 20:1. (photograph).

H20. "My Life In The Military Closet." July 11, 1993. P. VI $40: 1$. Jose Zuniga.

H21. "In Fear, Gay Soldiers Marry for Camouflage." July 12, 1993. P. A 10:5. Eric Schmitt, NYT staff.

H22. "Aspin Reported To Have settled on Gay Policy." July 14, 1993. P. A 1:2. Eric Schmitt, NYT staff.

H23. "Clinton Is Said to Accept Parts of Plan on Gay Ban." staff. July 16, 1993. P. A 10:5. Thomas L. Friedman, NYT

H24. "Accord Is Reached on Military Rules For Gay Soldiers." July 17, 1993. P. I 1:3. Thomas L. Friedman, NYT staff.

H25. "For the Military, Policing Sex Is Nothing New." July 17, 1993. P. I 7:4. Jane Gross.

H26. "Partial step on Gay Ban." July 18, 1993. P. I 18:6. Eric Schmitt, NYT staff. 
H27. "Clinton Caves In." July 18, 1993. P. IV 19:1. Bob Herbert.

H28. "Chiefs Back Clinton on Gay-Troop Plan." July 20, 1993. P. A 1:1. Thomas L. Friedman, NYT staff.

H29. "The Pentagon's New Policy Guidelines on Homosexuals in the Military." July 20, 1993. P. A 16:1.

H30. "Clinton In Crossfire." July 20, 1993. P. A 16:1. Richard I. Berke, NYT staff.

H31. "Military Gay Policy: Half a Loaf." July 20, 1993. P. A 18:1. (editorial).

H32. "'Don't Ask, Don't Tell.' Don't Believe It." July 20, 1993. P. A 19:2. William B. Rubenstein.

H33. "In Break for Clinton, Nunn Lends Support To GayTroop Plan." July 21, 1993. P. A 1:1. Eric Schmitt, NYT staff.

H34. (Corrections) July 21, 1993. P. A 1:7.

H35. "Gay Groups Denounce the Pentagon's New Policy." July 21, 1993. P. A 14:3. Sam Howe Verhovek.

H36. "At Fort Bragg, Reaction to Gay Policy Is Largely HoHum." July 21, 1993. P. A 14:1. David Margolick, NYT staff.

H37. "Don't Ask, Don't Drop the Soap." July 21, 1993. P. A 17:1. Douglas McGrath.

H38. "Military Praises Gay Policy For Ambiguity and Caution." July 22, 1993. P. A 14:1. Eric Schmitt, NYT staff.

H39. "Pentagon Keeps silent on Rejected Gay Troop Plan." July 23, 1993. P. A 12:4. Eric Schmitt, NYT staff.

H40. "What the Mayans could Teach the Joint Chiefs." July 23, 1993. P. A 27:2. Robert Bly.

H41. "President's Policy on Gay Troops Is Backed in Vote of Senate Panel." July 24, 1993. P. I 7:1. Eric Schmitt, NYT staff. 
H42. "No Easy Path for Legal Assault on New Gay Policy." July 25, 1993. P. I 22:1. Stephen Labaton, NYT staff.

H43. "Clinton's Gay Policy: Cave-In or Milestone?" July 25, 1993. P. IV 1:4. Thomas L. Friedman.

H44. "Homosexuals in service sue over clinton's Compromise." July 28, 1993. P. A 14:5. Stephen Labaton, NYT staff.

H45. "White House Plans to Fight For Discharge of Gay sailor." July 31, 1993. P. I 10:1.

H46. "Navy Searched Home of Civilian in a Gay Inquiry." Aug 1, 1993. P. I 35:1. (AP).

H47. "Discharged for Being Gay, He Leaves Uniform Behind." Aug 4, 1993. P. B $8: 3$. (photograph).

H48. "Clinton's Gay Rights Foray May Miscarry." Aug 9, 1993. P. A 14:5. (letter to editor).

H49. "Pornography Is Investigated At Marine Base in California." Aug 19, 1993. P. B 11:1. (AP).

H50. "He Who Barks Also Listens." Sep 2, 1993. P. C 1:2. Peter Applebome. 


\title{
APPENDIX B
}

SUMMARY OF STATEMENT CLASSIFICATIONS BY ARTICLE NUMBER

\author{
RACIAL MINORITIES
}

\section{Reformist}

$[57]$

Ideological

$1,3,3,3,3,3,4,4,5,5,5,6,6,8,8,8$, $8,8,9,10,11,11,12,13,13,14,15,16,17$, $17,17,18,18,19,21,21,21,22,22,22,23$, $23,23,23,23,24,25,25,26,26,26,26,26$, $27,29,30,31$.

[0] Interdependence

[7] Self-Cat

$7,18,18,27,27,2828$.

[7] Bureaucratic

$11,18,23,23,25,28,28$.

Exclusionist

[6] Ideological

$12,12,12,12,26,26$.

[6] Interdependence

$11,13,18,18,27,31$.

[10] Self-Cat

$7,11,13,16,18,24,31,31,31,31$.

[4] Bureaucratic

$16,31,31,31$.

Neutral Articles:

[2] 2,20 . 


\section{WOMEN}

\section{Reformist}

[70]

Ideological

$1,1,3,3,3,3,3,3,4,4,4,4,5,5,6,9$, $11,11,11,11,14,14,14,16,16,16,16,18$, $19,19,19,20,20,23,27,27,27,28,28,29$, $29,29,29,29,29,29,31,31,31,31,31,31$, $32,32,32,35,35,39,40,41,41,43,44,44$, $46,48,50,50,50,50$.

[0] Interdependence

[3] Self-cat

$4,31,39$.

[25] Bureaucratic

$1,1,1,3,3,3,3,3,3,3,3,3,3,10,12$, $12,15,16,29,29,30,30,37,41,50$.

\section{Exclusionist}

[14] Ideological

$3,3,3,3,3,3,35,35,35,36,37,46,48$, 50 .

[2] Interdependence

$39,39$.

[40] Self-Cat

$2,2,2,3,3,3,3,3,3,4,5,9,9,9,9,10$,

$10,15,15,15,16,16,31,31,32,33,35,35$,

$35,37,38,39,39,39,39,39,39,39,39,41$.

[49] Bureaucratic

$1,1,3,3,3,3,3,3,3,3,3,3,3,3,3,7$,

$9,14,15,16,22,22,22,24,25,25,25,32$, $32,34,37,41,41,41,41,42,44,44,44,47$, $50,50,50,50,50,50,50,50,50$.

\section{Neutral Articles:}


HOMOSEXUALS

\section{Reformist}

[132]

Ideological

$1,4,7,8,8,8,9,9,9,9,9,10,11,11,11$,

$11,12,13,14,15,15,15,15,15,16,16,16$,

$16,17,17,17,17,17,17,18,18,20,20,20$,

$20,20,21,21,22,22,22,22,23,24,24,24$,

$24,24,26,26,26,27,27,27,27,27,27,27$,

$28,28,28,28,28,30,30,30,30,30,30,30$,

$31,31,31,31,31,31,31,31,32,32,32,32$,

$32,32,32,32,32,32,32,32,32,32,32,35$,

$35,35,35,35,35,35,35,35,41,42,42,42$,

$42,42,42,42,42,42,42,42,42,42,42,43$,

$44,44,44,44,44,44,48,48,48$.

[15] Interdependence

$5,5,5,11,13,15,17,18,37,37,39,39,43$, 44,50 .

[9] Self-Cat

$2,5,9,11,17,30,31,32,35$.

[69] Bureaucratic

$1,3,3,3,3,3,3,4,5,5,5,5,10,11,15$, $15,17,20,20,22,23,24,24,24,24,26,26$, $28,28,28,28,28,29,29,29,29,29,29,29$, $29,31,31,31,31,31,31,31,31,32,32,32$, $32,35,35,35,35,36,38,38,39,39,42,42$, $44,44,44,44,44,44$.

Exclusionist

[14] Ideological

$1,1,1,3,3,4,4,5,20,32,39,44,44,45$.

[2] Interdependence

$11,39$.

[94] Self-Cat

$1,1,2,2,2,3,3,4,4,4,5,5,5,9,9,11$,

$11,11,11,11,13,13,13,14,14,14,14,14$,

$15,15,15,15,16,16,16,16,16,17,17,18$,

$18,18,18,20,20,20,20,20,23,29,30,30$,

$30,31,32,32,32,32,32,32,32,32,32,32$,

$35,36,36,36,36,36,36,36,36,36,37,37$,

$39,39,39,39,40,40,40,40,40,42,42,42$, 
$45,46,47,47,48,49$.

[18] Bureaucratic

$4,4,9,9,14,15,15,20,26,28,33,33,33$, $39,41,42,42,44$.

Neutral Articles:

[4] $6,19,25,34$. 